\title{
Novel nucleic acid analogs with a chimeric phosphinate / phosphate backbone; synthesis and biophysical properties
}

\author{
Barbara Nawrot,* Olga Michalak, Magdalena Janicka, Maria Maszewska, \\ Marzena Wojcik, Genowefa Nowak, Barbara Mikolajczyk, and Wojciech J. Stec \\ Department of Bioorganic Chemistry, Centre of Molecular and Macromolecular Studies, \\ Polish Academy of Sciences, Sienkiewicza 112, 90-363 Lodz, Poland \\ E-mail: bnawrot@bio.cbmm.lodz.pl
}

Dedicated to Professor Mieczyslaw Makosza on his $\mathbf{7 0}^{\text {th }}$ birthday

(received 29 Oct 03; accepted 16 Jan 04; published on the web 27 Feb 04)

\begin{abstract}
Novel analogs of acyclic nucleosides based on a bis-hydroxymethylphosphinic acid (BHPA) backbone were incorporated into a thymidine-containing DNA strand by phosphoramidite methodology. The physicochemical properties of these constructs were evaluated. Melting temperature measurements demonstrate that chimeric oligomers with a phosphinate / phosphate backbone possess lower binding affinity towards complementary single stranded templates and slightly higher binding affinity towards double stranded DNA, as compared to non-modified reference oligomers. The polyanionic oligomers containing BHPA abasic residue were also synthesized by the same methodology. These oligomers show low cytotoxic activity toward HUVEC and HeLa cell lines and, as expected, are resistant to nucleolytic degradation at the modification site.
\end{abstract}

Keywords: Acyclic nucleosides, DNA analog, bis-hydroxymethylphosphinic acid, hybridization properties, cytotoxicity

\section{Introduction}

DNA analogs with improved stability to nucleolytic degradation and higher binding affinity toward complementary DNA or RNA strands are of interest due to their potential application as therapeutics in antisense ${ }^{1}$ or antigene strategies. ${ }^{2}$ Several acyclic analogs of DNA, including those derived from isosteric glyceronucleosides, have been synthesized for these purposes up to now. ${ }^{3,4}$ Despite their improved flexibility those oligomers in most cases form weaker duplexes with complementary DNA or RNA strands, except in the case when increasing flexibility of the carbohydrate portion resulted in triplex stability. ${ }^{5}$ 
The aim of reported studies was the design of novel antisense / antigene therapeutics based on the use of a bis-(hydroxymethyl)phosphinic acid (BHPA) unit as a scaffold molecule. We assumed that bis-(hydroxymethyl)phosphinic acid could replace the 3'-, 4'- and 5'-carbons of the sugar moiety and provide a site for attachment of nucleobases via a one- or two-carbon linker. Esterified or amidated BHPA, if successfully incorporated into the oligonucleotide chain, were expected to possess an additional hydrogen bond acceptor site at the phosphinyl oxygen atom. The conformational flexibility and neutral nature of such a unit as in $\mathbf{2}$ could enhance cellular uptake, while attached nucleobases were expected to interact via stacking and hydrogen bonds with complementary DNA or RNA. Moreover, it was anticipated that even an abasic bis(hydroxymethyl)phosphinic unit, as in $\mathbf{1}$, could provide protection of chimeric constructs against nucleolytic degradation.

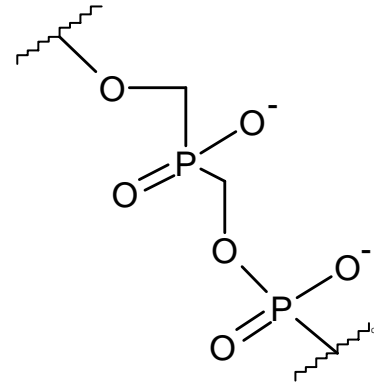

1

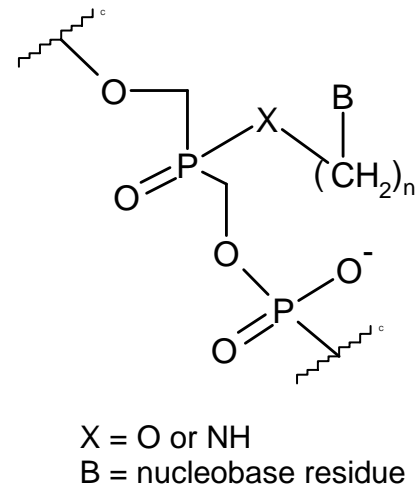

2

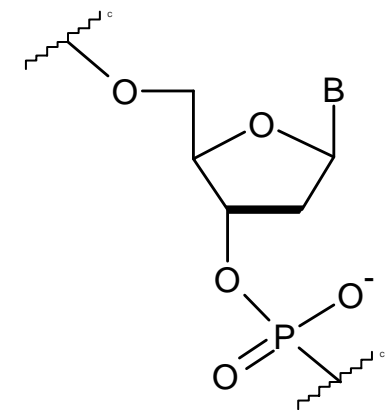

3

The use of a bis-(hydroxymethyl)phosphinic acid for the synthesis of acyclic nucleoside analogs and their successful incorporation into short DNA oligomers has been disclosed. ${ }^{6}$ Such acyclic nucleoside analogs were successfully used for the protection of deoxyribozymes, directed towards the HIV-1 viral RNA sequence in in vitro HIV-1 infected cellular experiments, ${ }^{7}$ as well as for deoxyribozymes designed to cleave $b c r-a b l$ mRNA fragments in in vitro experiments. ${ }^{8}$

In this paper we report on the synthesis of longer oligomers with a chimeric phosphinate / phosphate backbone and the evaluation of the biophysical properties of such constructs, including their affinity toward RNA and DNA templates, their stability in the presence of 3'- and 5'-exonucleases, and their cytotoxic activity in selected cell lines.

\section{Results and Discussion}

\section{Synthesis of thymidine analogs}

Acyclic thymidine analogs were obtained either by condensation of the bis(4,4'-dimethoxytrityl) derivative of BHPA with $N$-1- or N-3-(2-hydroxyethyl)thymine in the presence of MSNT, or by an Appel-type reaction ${ }^{9}$ with $N-1$ - or $N$-3-(2-aminoethyl)thymine, as described in our previous 
$\operatorname{paper}^{6}$ (Scheme 1). Both hydroxyl groups of bis-(hydroxymethyl)phosphinic acid methyl ester ${ }^{10}$ (4) were protected with acid-labile 4,4'-dimethoxytrityl (DMT) groups. The fully protected derivative 5 was demethylated with tert-butylamine at $100{ }^{\circ} \mathrm{C}$ (sealed tube) affording salt $\mathbf{6}$. BHPA esters $7 \mathbf{a}$ and $\mathbf{7 b}$ could be synthesized in good yields ( 74 and $75 \%$, respectively) by condensation of 6 with $N-1-^{11}$ or $N$-3-(2-hydroxyethyl)thymine ${ }^{12}$ in the presence of 1-(2mesitylenesulfonyl)-3-nitro-1,2,4-triazole (MSNT) as activator. To obtain 7c and 7d, phosphinate $\mathbf{6}$ was subjected to an Appel-type reaction with $\mathrm{N}-1-$ or $\mathrm{N}-3-(2-$ aminoethyl)thymine. ${ }^{12}$

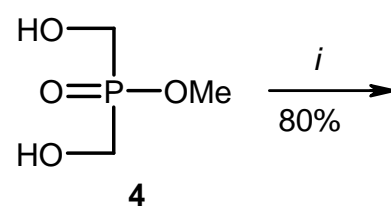

4

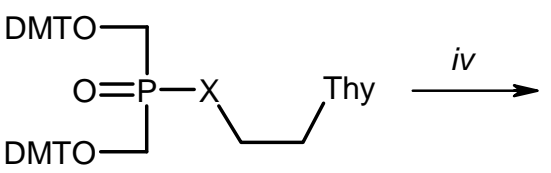

7a-d

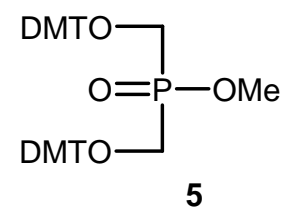

5
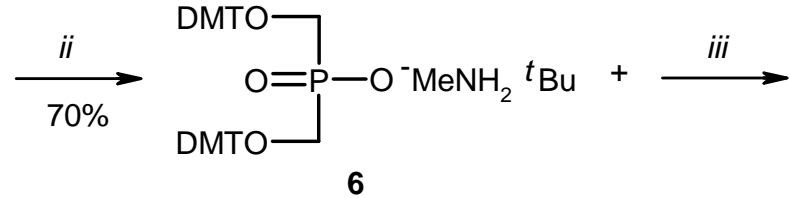
a, $\mathbf{b}: X=0$
c, d: $\mathrm{X}=\mathrm{NH}$
a, c: Thy = thymin-1-yl
b, d: Thy = thymin-3-yl
a-d: $\mathrm{R}=\mathrm{CH}_{2} \mathrm{CH}_{2} \mathrm{CN}$
a, b: $\mathrm{R}=\mathrm{CH}_{3}$

$$
\begin{aligned}
& \text { DMTO } \\
& \text { HO } \\
& \text {-yl } \\
& \text {-yl } \\
&
\end{aligned}
$$
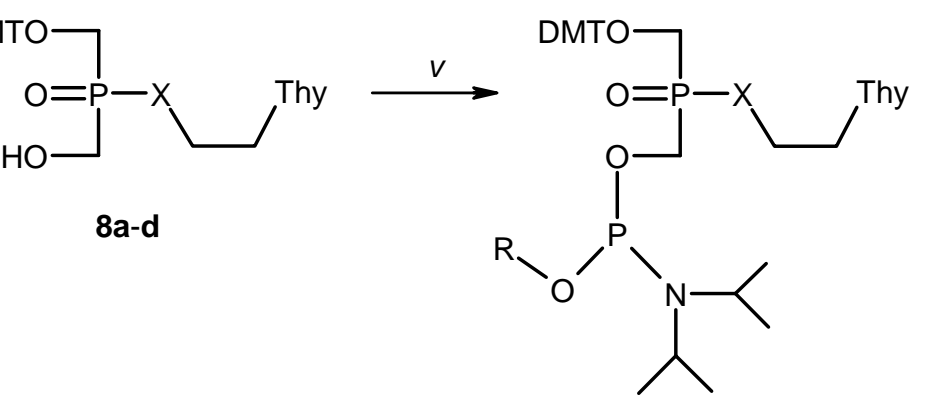

9a-d

Scheme 1. Reagents and conditions: (i) 4,4'-dimethoxytrityl (DMT) chloride (2.5 eq.) / pyridine, $12 \mathrm{~h}, \mathrm{RT}$; (ii) tert-butylamine $(6 \mathrm{eq}), 100{ }^{\circ} \mathrm{C}, 10 \mathrm{~h}$; (iii) $\mathrm{N}-1$ or $N$-3-(2-hydroxyethyl)thymine (1 eq.), MSNT (1 eq.) in pyridine, $24 \mathrm{~h}$, RT or (2-aminoethyl)thymine (1 eq.), $\mathrm{PPh}_{3}$ (3 eq.), $\mathrm{CCl}_{4}(5$ eq.) in pyridine, RT, $24 \mathrm{~h}$; (iv) toluene-4-sulfonic acid in methanol (0.02 M, 0.8 eq.), RT, $5 \mathrm{~min}$, then pyridine, (v) O-2-cyanoethyl- $N, N, N^{\prime}, N^{\prime}$-tetraisopropylphosphordiamidite (1.2 eq.) and 2ethylthio- $1 H$-tetrazole (2.4 eq.) in acetonitrile, RT, $1 \mathrm{~h}$.

This reaction was carried out in pyridine in the presence of triphenylphosphine (3 eq.) and carbon tetrachloride (5 eq.). The yields of the desired products were rather low (25-30\%). Physicochemical characteristics of compounds 7a-d are presented in Table 1. 
Table 1. Spectral and chromatographic data for bis-(hydroxymethyl)phosphinic acid derivatives 7 - 9. Yields of the transformation reaction of the salt 6 to amidated or esterified BHPA derivatives 7a-d (in \%) are also given

\begin{tabular}{lllll}
\hline Comp. & Yield (\%) & $\mathrm{R}_{\mathrm{f}}(\mathrm{TLC})^{a}$ & FAB MS m/z & $\delta^{31} \mathrm{P}$ NMR $(\mathrm{ppm})$ \\
\hline $\mathbf{7 a}$ & 74 & 0.34 & $882.6[\mathrm{M}+\mathrm{H}]$ & 49.10 \\
& & & $881.8[\mathrm{M}-\mathrm{H}]$ & \\
$\mathbf{7 b}$ & 75 & 0.22 & $881.8[\mathrm{M}-\mathrm{H}]$ & 48.43 \\
$\mathbf{7 c}$ & 30 & 0.58 & $882.8[\mathrm{M}+\mathrm{H}]$ & 38.55 \\
& & & $880.3[\mathrm{M}-\mathrm{H}]$ & \\
$\mathbf{7 d}$ & 25 & 0.42 & $880.6[\mathrm{M}-\mathrm{H}]$ & 37.35 \\
$\mathbf{8 a}$ & 35 & 0.61 & $579.3[\mathrm{M}-\mathrm{H}]$ & 48.75 \\
$\mathbf{8 b}$ & 33 & 0.50 & $579.1[\mathrm{M}-\mathrm{H}]$ & 50.65 \\
$\mathbf{8 c}$ & 32 & 0.82 & $578.2[\mathrm{M}-\mathrm{H}]$ & 38.26 \\
$\mathbf{8 d}$ & 30 & 0.73 & $578.3[\mathrm{M}-\mathrm{H}]$ & 37.51 \\
$\mathbf{9 a} \mathbf{a}^{c}$ & 70 & 0.32 & & $153.37 ; 153.0 ; 46.96 ; 46.59^{b}$ \\
$\mathbf{9 b}^{d}$ & 60 & 0.42 & & $152.69 ; 152.31 ; 46.32 ; 46.16^{b}$ \\
$\mathbf{9 c}^{d}$ & 75 & 0.48 & & $152.10 ; 152.00 ; 151.96 ; 151.86 ;$ \\
& & & & $36.59 ; 36.53 ; 36.44 ; 36.39^{b}$ \\
$\mathbf{9 d}^{d}$ & 50 & 0.50 & & $151.92 ; 151.61 ; 36.37 ; 36.00^{b}$ \\
\hline
\end{tabular}

${ }^{a} \mathrm{CHCl}_{3} / \mathrm{MeOH}, 9: 1, \mathrm{v} / \mathrm{v}$.

${ }^{b}$ The multiple resonances (four or eight signals) may be due to the presence of threo-erythro diastereoisomerism and/or P-C-O-P spin couplings.

${ }^{c}$ methyl-protection of phosphoramidite residue.

${ }^{d}$ 2-cyanoethyl-protection of phosphoramidite residue.

The derivatives 7a-d were subsequently subjected to selective removal of one DMT group by short treatment with toluene-4-sulfonic acid in methanol $(0.02 \mathrm{M}, 0.8$ eq.). The reaction had to be stopped after 5-6 min while $c a .60 \%$ of substrate was still present in the reaction mixture. Extended reaction times led to significant amounts of fully deprotected BHPA ester or amide derivatives resulting from their further decomposition due to P-O and P-N bond cleavage. Therefore, the reactions were terminated by addition of an excess of pyridine. The desired products were isolated by means of preparative TLC with recovery of ca. $60 \%$ of starting material. This procedure could be repeated until the entire substrate was deprotected affording the desired 8a-d in ca. 30-35\% yield. Compounds 8a-d, containing P-chiral center, were used as racemic mixtures for further transformations. Phosphitylation ${ }^{13}$ of the free $\mathrm{OH}$ group in 8a-d by means of $O$-2-cyanoethyl- $N, N, N^{\prime}, N^{\prime}$-tetraisopropylphosphordiamidite (1.2 eq.) was carried out in anhydrous acetonitrile in the presence of 2-ethylthio- $1 \mathrm{H}$-tetrazole (2.4 eq.) providing the acyclic nucleoside phosphoramidite synthons $\mathbf{9 a - d}$. 


\section{Synthesis of oligomers with a chimeric phosphinate / phosphate backbone Short oligomers}

In our previous communication we described conditions for the incorporation of the modified BHPA units 9a-d into short DNA oligomers. ${ }^{6}$ The phosphoramidite monomers 9 and conventional phosphoramidite monomers were used as substrates for the synthesis of our constructs by automated phosphoramidite methodology. ${ }^{14}$ The synthesis was performed on an ABI 394 synthesizer (Applied Biosystem Inc., Foster City, CA) using succinyl- either oxalyllinked $^{15}$ LCA-CPG solid supports. The only difference in the procedure recommended by manufacturer was a prolonged coupling time of the modified monomers (up to $600 \mathrm{~s}$ ). The coupling efficiency of 9a-d, as determined by DMT-ion assay, was in the range of 95-97\%. The 5 '-terminal DMT group was usually removed before cleavage of the product from the solid support.

While the synthesis of trimers dApYpdC $\mathbf{1 0}$ (where $\mathrm{Y}$ is a modified BHPA unit as in 2, $\mathrm{B}=$ thymin-1-yl or thymin-3-yl, $\mathrm{n}=2$ ) followed by a standard ammonia deprotection and RP HPLC purification led to the desired amidate derivatives 10c and 10d, this approach did not yield the esterified derivatives 10a and 10b (Table 2, a-d as in Scheme 1). Instead, as revealed by MALDI-TOF analysis, both isolated products in fact constituted the same compound 11, possessing a BHPA unit with depleted alkyl-nucleobase moiety ( $\mathrm{Y}^{\mathrm{ab}}$, see table 2$)$. In this case hydrolytic deprotection conditions (concentrated aqueous ammonia, $16 \mathrm{~h}, 55^{\circ} \mathrm{C}$ ) resulted in cleavage of the ester bond of the phosphinic acid derivatives 10a and 10b, giving rise to anionic DNA analogs with a pseudo-abasic site (as presented in the structure 1). This instability of the BHPA ester bond of 10a and 10b was also observed under less harsh conditions, routinely used for the cleavage of oligomers from the solid support $\left(28 \%\right.$ aq. $\left.\mathrm{NH}_{4} \mathrm{OH}, 1 \mathrm{~h}, 20^{\circ} \mathrm{C}\right)$. Despite the observed stability of the ester bond of $7 \mathbf{a}$ and $7 \mathbf{b}$ in concentrated aqueous ammonia ( $2 \mathrm{~h}$ at RT data not shown), we considered that such compounds, as base-labile phosphotriester analogs, ${ }^{16}$ might not survive the deprotection conditions during DNA synthesis.

This result, albeit expected for those phosphotriester analogs, ${ }^{17}$ convinced us that the routine phosphoramidite methodology could not be used for the synthesis of the modified oligomers containing nucleotide units with required protection of nucleobases. However, application of an oxalyl-LCA CPG solid support ${ }^{15}$ and methyl-phosphoramidite methodology ${ }^{14}$ allowed us to obtain homo-thymidylates TpTpYpYpTpT (12a and 12b). ${ }^{6}$ Removal of the phosphate protecting methyl groups was achieved by treatment of solid support-bound oligomers with a thiophenol / dioxane / triethylamine mixture $(2: 1: 2, \mathrm{v} / \mathrm{v})$ for $5 \mathrm{~min}$ at RT, followed by the release of oligomers from the solid support by treatment with $1 \%$ aqueous triethylamine for $7-10$ min at RT. Expected oligomers were also obtained by using an oxalyl-LCA CPG solid support and protection of the phosphate function with a 2-cyanoethyl group. In this case treatment of solid support-bound oligomers with $1 \%$ aqueous triethylamine for $10 \mathrm{~min}$ at room temperature resulted in simultaneous release of the oligomer and removal of the 2-cyanoethyl protecting groups. The basic conditions used were sufficient for release of the oligomer from the solid support without hydrolytic cleavage of the P-O bond. 
Table 2. Chromatographic and spectral characteristics of chimeric DNA analogs containing bis(hydroxymethyl)phosphinic acid residues (Y)

\begin{tabular}{|c|c|c|c|c|}
\hline \multirow[t]{2}{*}{ Compound $^{a}$} & \multirow{2}{*}{$\begin{array}{c}\text { Sequence of ODN } \\
\left(5^{\prime} \rightarrow 3^{\prime}\right)\end{array}$} & \multirow{2}{*}{$\begin{array}{l}\mathrm{HPLC}^{c} \\
\mathrm{R}_{\mathrm{t}}(\min )\end{array}$} & \multicolumn{2}{|c|}{ MALDI-TOF } \\
\hline & & & calc. & found \\
\hline $10 \mathrm{c}$ & dApYpdC & 16.15 & 878 & 879 \\
\hline 10d & dApYpdC & 17.10 & 878 & 878 \\
\hline 11 & $\mathrm{dAp} \mathrm{Y}^{\mathrm{ab}} \mathrm{pdC}^{b}$ & 13.49 & 725 & 727 \\
\hline $12 \mathbf{a}$ & ТрТрYрYрTрT & 20.06 & 1828 & 1835 \\
\hline $12 b$ & TpTpYpYpTpT & 20.63 & 1828 & 1833 \\
\hline 13 & $(\mathrm{Tp})_{9} \mathrm{Y}^{\mathrm{ab}}(\mathrm{pT})_{9}$ & 10.25 & 5598 & 5600 \\
\hline 14 & $(\mathrm{Tp})_{8} \mathrm{Y}^{\mathrm{ab}} \mathrm{pY}^{\mathrm{ab}}(\mathrm{pT})_{9}$ & 9.57 & 5482 & 5485 \\
\hline 15 & $\mathrm{Y}^{\mathrm{ab}} \mathrm{p}(\mathrm{Tp}){ }_{17} \mathrm{Y}^{\mathrm{ab}}$ & 9.19 & 5482 & 5484 \\
\hline 16 & $\mathrm{Y}^{\mathrm{ab}}(\mathrm{pdA})_{17} \mathrm{p} \mathrm{Y}^{\mathrm{ab}}$ & 8.37 & 5635 & 5638 \\
\hline 17 & $\mathrm{dCp}\left(\mathrm{Y}^{\mathrm{ab}} \mathrm{p}\right)_{17} \mathrm{dC}$ & 8.67 & 3712 & 3709 \\
\hline 18 & Fl-dCp $\left(\mathrm{Y}^{\mathrm{ab}} \mathrm{p}\right)_{17} \mathrm{~d} \mathrm{C}^{d}$ & 12.25 & 4246 & 4244 \\
\hline $19 \mathbf{a}$ & $(\mathrm{Tp})_{9} \mathrm{Y}(\mathrm{pT})_{9}$ & 20.87 & 5750 & 5754 \\
\hline $19 \mathrm{c}$ & $(\mathrm{Tp})_{9} \mathrm{Y}(\mathrm{pT})_{9}{ }^{e}$ & 23.76 & 6051 & 6053 \\
\hline $20 a$ & $(\mathrm{Tp})_{8} \mathrm{YpY}(\mathrm{pT})_{9}$ & 21.52 & 5786 & 5792 \\
\hline $20 \mathrm{c}$ & $(\mathrm{Tp})_{8} \mathrm{YpY}(\mathrm{pT})_{9}{ }^{e}$ & 23.96 & 6086 & 6092 \\
\hline $21 \mathrm{a}$ & $(\mathrm{Tp})_{8} \mathrm{YpYpY}(\mathrm{pT})_{8}$ & 22.01 & 5822 & 5824 \\
\hline $21 \mathrm{c}$ & $(\mathrm{Tp})_{8} \mathrm{YpYpY}(\mathrm{pT})_{8}{ }^{e}$ & 24.00 & 6121 & 6120 \\
\hline
\end{tabular}

${ }^{a} \mathbf{a}$ - $\mathbf{d}$ are according to Scheme 1.

${ }^{b} \mathrm{Y}^{\mathrm{ab}}$ is ionic bis(hydroxymethyl)phosphinic acid residue as in $\mathbf{1}$.

${ }^{c}$ Analytical RP HPLC was performed on a C18 (4.6 x $250 \mathrm{~mm}$, ThermoQuest) column with a linear gradient of acetonitrile in $0.1 \mathrm{M}$ triethylammonium bicarbonate $\mathrm{pH} 7.5$ buffer $(0-20 \mathrm{~min} /$ 0-20\% $\mathrm{CH}_{3} \mathrm{CN}, 20-25 \mathrm{~min} / 20-40 \% \mathrm{CH}_{3} \mathrm{CN}$, flow rate $\left.1 \mathrm{~mL} / \mathrm{min}\right)$. For compounds 13-18, 19c, 20c and 21c retention times are given for semi-preparative RP HPLC performed on a C18 PRP-1 column (Hamilton) at the same buffer system, flow rate $3 \mathrm{~mL} / \mathrm{min}$.

${ }^{d} 5$ '-fluorescein labeled polyanionic oligomer $(\mathrm{Fl})$.

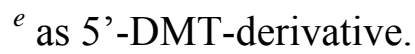

Chimeric oligomers $\mathbf{1 0}$ and $\mathbf{1 2}$ were synthesized as diastereomeric mixtures by virtue of a chiral center at the phosphorus atom of the BHPA moiety. In spite of our efforts neither trimers 10c and 10d nor hexamers 12a and 12b could be separated by HPLC in the form of P-chiral pure diastereomers. 


\section{Substrates for the synthesis of abasic DNA analogs}

A much simpler synthetic route to the anionic DNA analogs 1 could be used starting from bis(hydroxymethyl)phosphinic acid methyl ester 4. Dimethoxytritylation of one of $\mathrm{OH}$ groups in 4 followed by phosphitylation of the resulting $8 \mathbf{e}$ led to phosphoramidite monomer $9 \mathbf{e}$ (Scheme 2). Monomer 9e could be used for the synthesis of pseudo-abasic DNA analogs, either those possessing a $\mathrm{Y}^{\mathrm{ab}}$ group within the oligomer chain, or at the 5'-end of the construct. For introduction of the abasic BHPA unit at the 3 '-end of the oligomer derivative 8e was acylated with succinic anhydride in pyridine and then coupled with an aminoalkyl linker of controlled pore glass solid support (LCA CPG). This modified solid support 9f was loaded with the BHPA derivative up to $57.0 \mu \mathrm{mol} / \mathrm{g}$, as determined by a DMT-cation assay and used for the synthesis of 3'-modified chimeric DNA analogs.

\section{Synthesis of longer chimeric DNA analogs - compounds 13-21}

Our preliminary experiments led us to the following conclusions:

- the routine phosphoramidite strategy has proved to be successful for the synthesis of the short chimeric oligomers containing BHPA amidate units;

- esterified BHPA analogs can be introduced only into homo-thymidylate oligomers exclusively via an oxalyl-linked solid support approach;

- anionic abasic analogs of DNA can be obtained from an easily accessible monomer (DMT protected phosphoramidite of BHPA methyl ester) 4.

Therefore, this methodology was used for the synthesis of numerous longer oligomers with phosphinate / phosphate backbone.

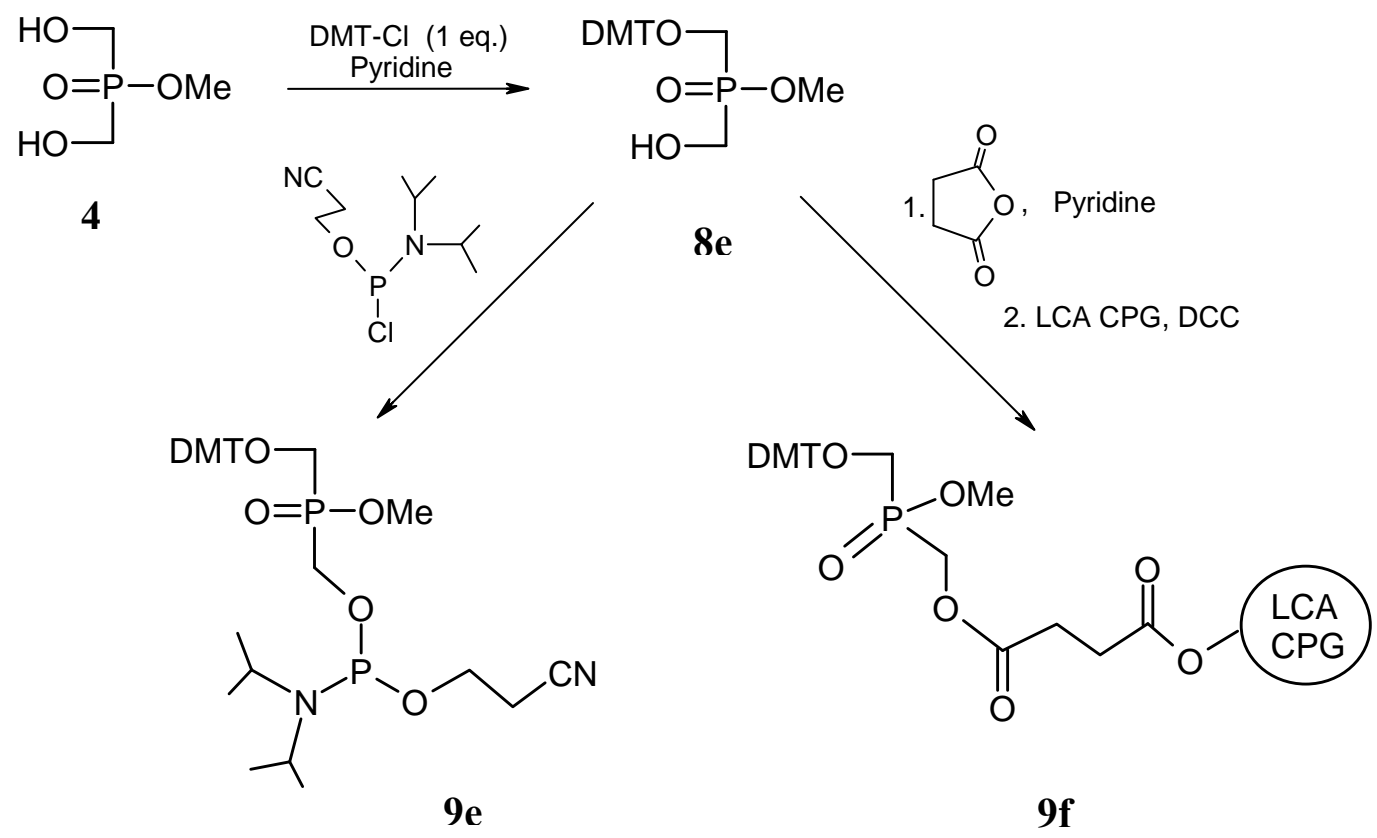

Scheme 2. Synthesis of phosphoramidite derivative of BHPA methyl ester 9e and solid support bound BHPA methyl ester. 
To study the properties of the abasic DNA analogs ${ }^{18}$ containing ionic bis(hydroxymethyl)phosphinic acid residues as in 1, one or two BHPA units $\left(\mathrm{Y}^{\mathrm{ab}}\right)$ were introduced into the central domain of the longer homo-thymidylate chain, as in 13 and 14, respectively, or were used for 3'- and 5'-terminal protection of the DNA chain, as in $\mathbf{1 5}$ and 16. The polyanionic oligomer $\mathrm{dCp}\left(\mathrm{Y}^{\mathrm{ab}} \mathrm{p}\right)_{17} \mathrm{dC} \mathbf{1 7}$ and its 5'-fluorescently labeled analog 18 were also synthesized by the same methodology. Compounds 13-17, due to their stability under acidic conditions, were synthesized as 5'-DMT-protected oligomers (DMT-ON) and separated from shorter by-products by reverse phase HPLC. ${ }^{19}$ Subsequent removal of the 5'-terminal DMT group, followed by a second RP HPLC purification, resulted in pure ( $>95 \%$ ) oligomers 13-16. Representative HPLC profiles of semi-preparative purification of oligomer 15 at DMT-ON and DMT-OFF steps are shown at Figure 1a and 1b, respectively.

a

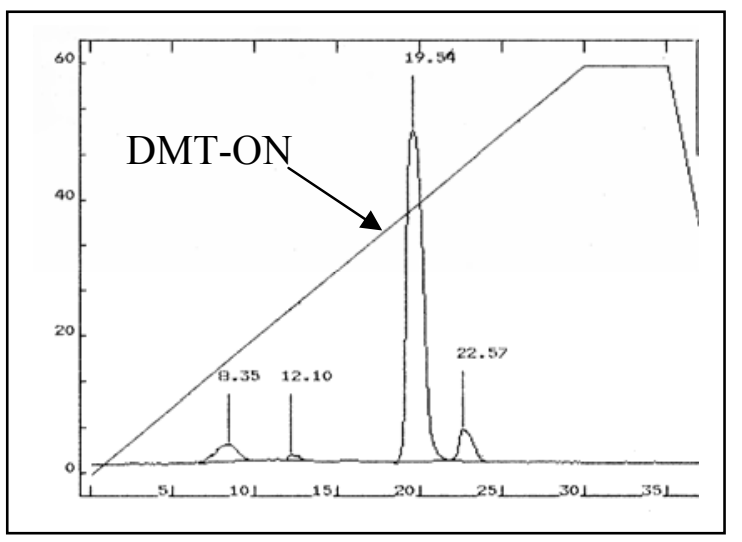

b

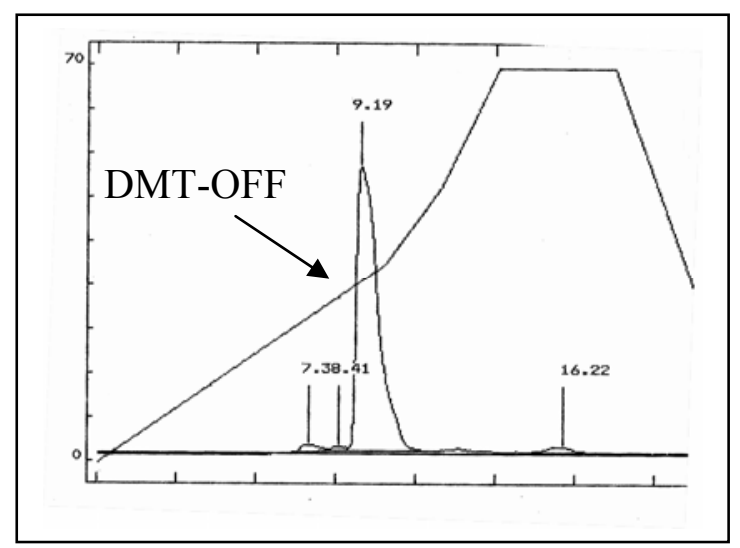

Figure 1. Semi-preparative purification of oligomer $\mathrm{Y}^{\mathrm{ab}} \mathrm{p}(\mathrm{Tp}){ }_{17} \mathrm{Y}^{\mathrm{ab}}$ (15) by the two step deprotection / purification procedure. ${ }^{19}$ RP HPLC profiles are shown for purification of the 5'DMT- $\mathrm{Y}^{\mathrm{ab}} \mathrm{p}(\mathrm{Tp}){ }_{17} \mathrm{Y}^{\mathrm{ab}}$ oligomer, step DMT-ON (a) and fully deprotected oligomer $\mathrm{Y}^{\mathrm{ab}} \mathrm{p}(\mathrm{Tp}){ }_{17} \mathrm{Y}^{\mathrm{ab}}$, step DMT-OFF (b). Collected were oligomers with retention time $19.54 \mathrm{~min}$ (a) and $9.19 \mathrm{~min}$ (b). HPLC deatils are described in Experimental.

Purity of compounds 13 - 18 was checked by $20 \%$ polyacrylamide / $7 \mathrm{M}$ urea gel electrophoresis (PAGE). For compounds 13, 14 and 17 PAGE analysis was done on the 5'- ${ }^{32} \mathrm{P}-$ labeled oligomers. Representative PAGE gels of oligomers 13 and 14 as well as 15 and 16 are show at Figure $2 \mathrm{a}$ and $\mathrm{b}$ respectively. Nonadecadeoxyadenylate $\mathrm{dA}_{19}$ and nonadecathymidylate $\mathrm{T}_{19}$ are used as the reference oligomers. Electrophoretic mobility of oligomers 13 and 14 (Figure $2 a$ ) is slightly higher than that of the reference $T_{19}$ due to the presence of the $Y^{\mathrm{ab}}$ units increasing total negative charge of the chimeric oligomers 13 and 14. 


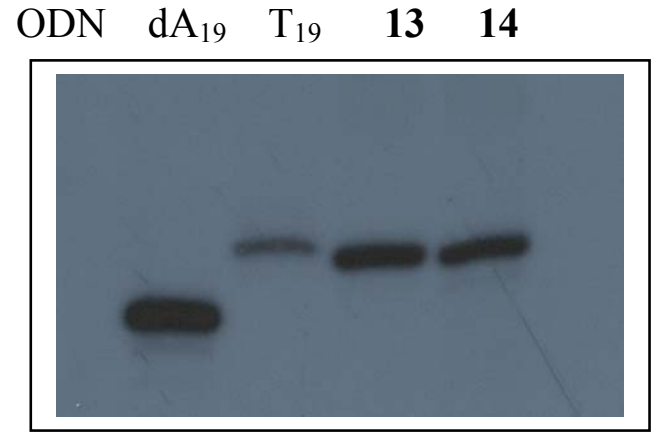

a

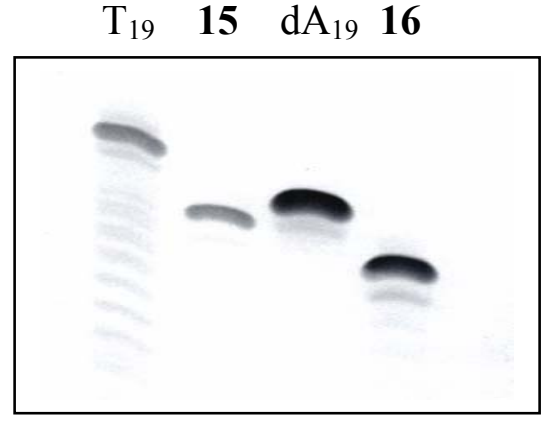

b

Figure 2. Analysis of purity of oligomers 13 - 16 by $20 \%$ polyacrylamide / 7 M urea gel electrophoresis. $\mathrm{dA}_{19}$ and $\mathrm{T}_{19}$ oligomers are used as the reference oligomers; Figure a: oligomers 13 and 14 as well as the reference oligomers were used for analysis as $5,{ }^{32} \mathrm{P}$-labeled derivetives, Figure b: detection of tested oligomers was done with Stains all reagent.

The structure of the 5'-fluorescently labeled oligomer 18 was confirmed by MALDI-TOF analysis (Figure 3a) and its purity was checked by PAGE analysis. Band visualisation was achived by means of a Stains all reagent (Figure 3b). For comparison mobility of 5 , $-{ }^{32}$ P-labeled oligomer 17 was checked by analogous PAGE analysis (Figure 3c). At this gel the spot of 5'fluorescently labeled oligomer 18 could be seen in the UV light and was marked at the autoradiogram film as shown. Oligomer 17 exhibits higher mobility at the polyacrylamide gel. This oligomer is contaminated in ca. $10 \%$ of with the product of lower PAGE mobility. This impurity could be neither separated from oligomer 17 by RP HPLC nor identified by MALDITOF mass spectrometry.

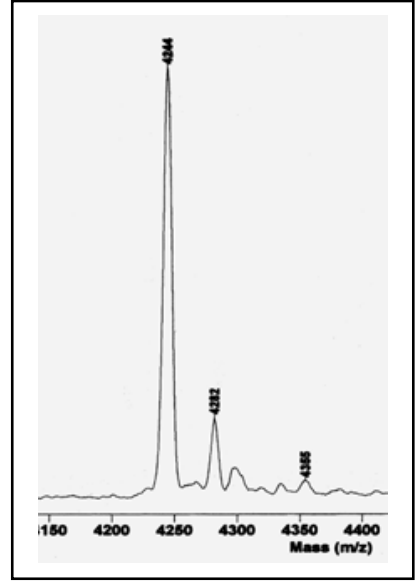

a

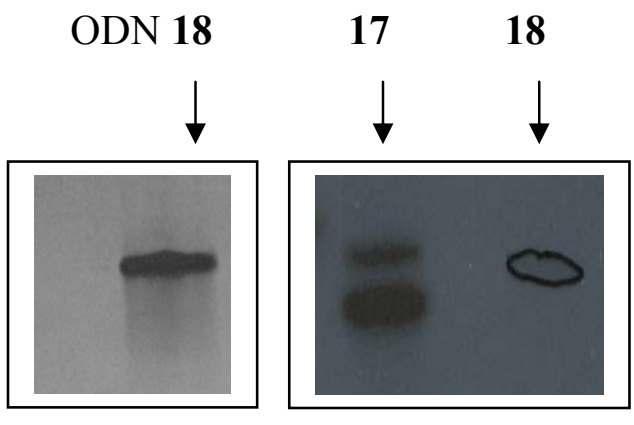

$\mathrm{b}$

C

Figure 3. Spectral and electrophoretic analysis of polyanionic oligomers 17 and 18. a: MALDITOF spectrum of oligomer 18 (m/z 4244, calc. 4246); b: $20 \%$ polyacrylamide / $7 \mathrm{M}$ urea gel electrophoresis with band visualisation in Stains all reagent; c: PAGE of 5'-32 P-labeled oligomer 17 and its 5'-fluoresently labeled analog 18. The spot of the oligomer 18 visible in the UV light on the gel was as marked at the autoradiogram film as shown. 
Monomers 9a and 9c, mimicking acyclic DNA nucleosides ( $N$-1-substituted thymine), were used for the synthesis of nonadecathymidylate analogs 19, 20 and 21, containing incorporated one, two or three BHPA units, respectively.

Oligonucleotides 19a-21a, possessing esterified BHPA units, due to their rather low stability either in basic and acidic conditions, were obtained as fully deprotected oligomers. The yields of these oligomers, after RP HPLC separation, were rather moderate (10-15 optical units from 1 $\mu$ mol DNA synthesis).

For the synthesis of oligomers 19c-21c containing BHPA amidate units we used a two step deprotection / purification procedure. ${ }^{19}$ After the synthesis was completed, oligomers 19c-21c were released from the solid support as the 5'-DMT-protected derivatives. Shorter by-product oligomers were separated chromatographically from the desired, DMT-containing hydrophobic oligomers, which then were exposed to acidic conditions (3\% TFA in dichloromethane). These conditions were safe during the automated synthesis of oligomers and were supposed to be suitable for final deprotection of the terminal 5'-OH group of 19c-21c. Unfortunately, all our efforts to obtain the desired fully deprotected oligomers without cleavage of the P-N bond have failed, even if the time of the reaction was as long as required for the removal of the DMT group during the DNA solid phase synthesis. Thus, we concluded that the removal of the 5'-terminal DMT protecting group should be carried out before the release of the oligomer from the solid support, as we proved by the successful synthesis of the trimer dApYpdC 10c. ${ }^{6}$ No other methods of removal of DMT group as e.g. using $\mathrm{ZnBr}_{2}{ }^{20}$ were tested.

For evaluation of biophysical properties oligomers 19a-21a were used as fully deprotected species, and oligomers 19c-21c as 5'-DMT-protected constructs. The structures of all oligomers listed in Table 2 were confirmed by MALDI-TOF mass spectrometry, and their purity was confirmed by HPLC analysis. As determined by analytical RP HPLC the purity of oligomers 1921 was ca. 98-99 \%. Representative analytical HPLC profile and MALDI-TOF mass spectrum of oligonucleotide 19a are shown in Figure $4 \mathrm{a}$ and $4 \mathrm{~b}$, respectively. In the mass spectrum molecular ion with $\mathrm{m} / \mathrm{z} 5754$ represents oligomer 19a (MW 5750), while a minute peak at $\mathrm{m} / \mathrm{z} 5602$ gives rise from $\left[\mathrm{M}-\mathrm{CH}_{2} \mathrm{CH}_{2} \mathrm{Thy}\right]^{+}$fragmentation ion or decomposition product $(\mathrm{Tp})_{9} \mathrm{Y}^{\mathrm{ab}}(\mathrm{pT})_{9}$.

Oligomers containing a 5'-DMT-protecting group and amidated BHPA units showed remarkable instability in MALDI-TOF experimental conditions due to the presence of the acid labile 5'-DMT protecting group and of the acid-labile amide P-N bond. A representative analytical HPLC profile and MALDI-TOF spectrum of oligonucleotide 19c are shown at Fig. 5a and $5 \mathrm{~b}$, respectively. The profile of analytical RP HPLC analysis shows exclusively one peak representing oligomer 19c and the MALDI-TOF mass spectrum confirms the presence of the expected product giving a signal at $\mathrm{m} / \mathrm{z} 6053$ (calc. 6051). However, due to instability of compound 19c in the conditions used for the MS analysis, oligomer 5'-DMT-(Tp) ${ }_{9} \mathrm{Y}(\mathrm{pT})_{9}$, where $\mathrm{Y}$ is BHPA-NH- $\mathrm{CH}_{2} \mathrm{CH}_{2}$ Thy moiety, undergoes an acidic hydrolysis resulting in the appearance the three other products of the following MS signals: at $\mathrm{m} / \mathrm{z} 5901$ for product 5'-DMT$(\mathrm{Tp})_{9} \mathrm{Y}^{\mathrm{ab}}(\mathrm{pT})_{9}$ (calc. 5900), at $\mathrm{m} / \mathrm{z} 5751$ for product $(\mathrm{Tp})_{9} \mathrm{Y}(\mathrm{pT}) 9$ (calc. 5749) and at $\mathrm{m} / \mathrm{z} 5599$ for product $(\mathrm{Tp})_{9} \mathrm{Y}^{\mathrm{ab}}(\mathrm{pT})_{9}$ (calc. 5598). Similar MALDI-TOF mass spectra were obtained for 
oligomers 20c and 21c, while HPLC profiles of these compounds univocally confirmed their analytical purity (>99\%).

a

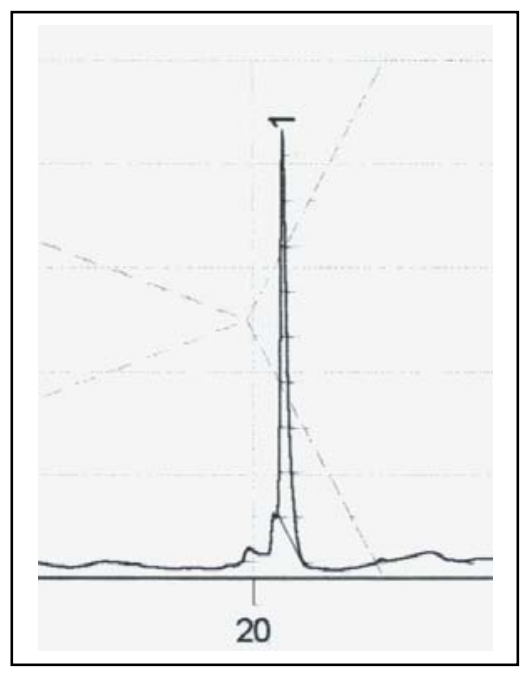

b

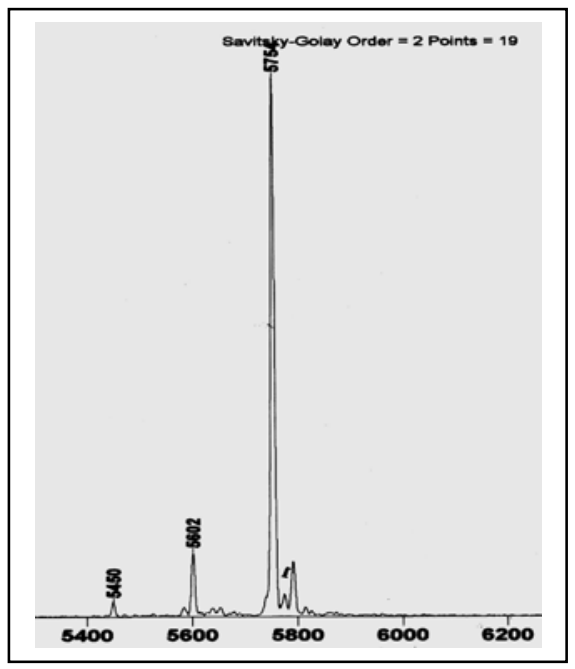

Figure 4. Analytical RP HPLC profile (a) and MALDI-TOF spectrum (b) of oligonucleotide 19a. Chromatographic analysis conditions are given in Experimental.

\section{$\mathrm{a}$}

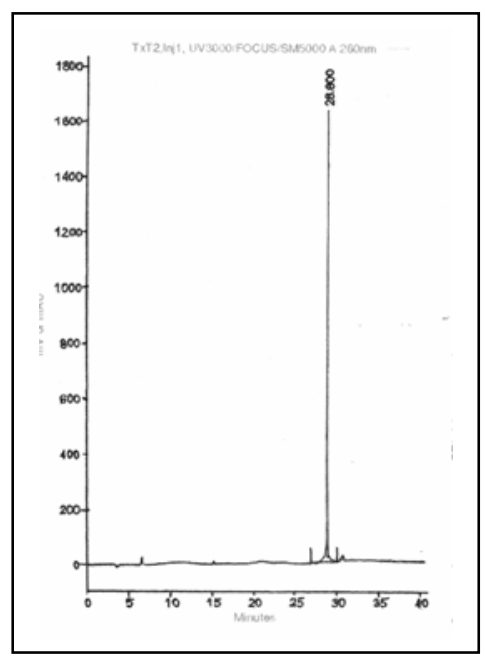

b

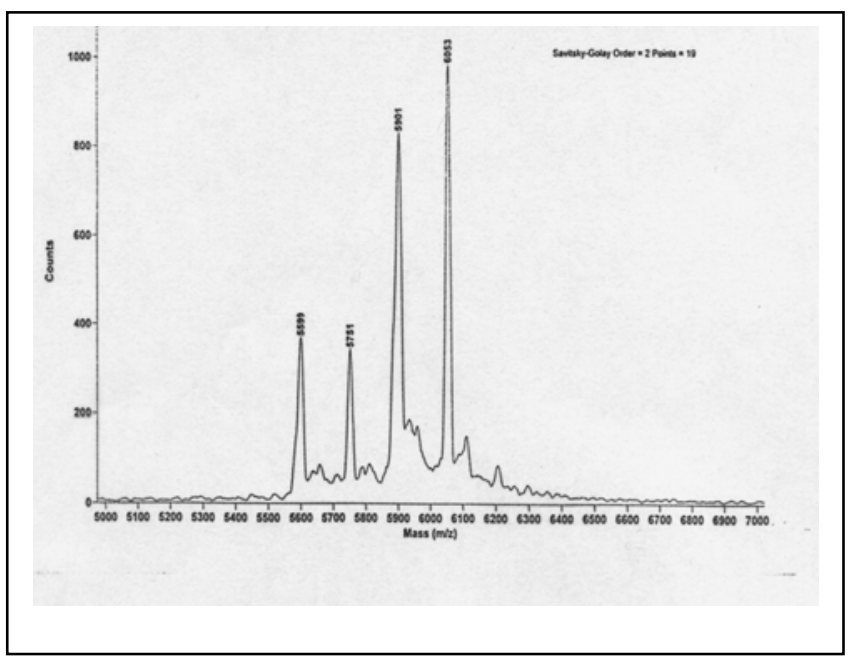

Figure 5. Analytical RP HPLC analysis and MALDI-TOF mass spectrum of oligomer 19c. HPLC profile shows high ( $>99 \%)$ purity of compound 19c. The MALDI-TOF mass spectrum shows the expected $\mathrm{m} / \mathrm{z}$ signal at 6063 , while three other signals representing the parent oligonucleotide degradation / fragmentation products are seen in MALDI-TOF mass spectra. 


\section{Hybridization properties of chimeric phosphinate / phosphate backbone oligomers}

The affinity of polymers 13-16 and 19-21 toward complementary DNA and RNA strands as well as double stranded DNA was determined by UV thermal melting measurements. The Tm values of investigated duplexes and triplexes are given in Table 3. Introduction of anionic BHPAderived abasic sites $\left(\mathrm{Y}^{\mathrm{ab}}\right)$ into the DNA chain, as in chimeric oligomers 13 and 14, causes remarkable destabilization of the corresponding duplexes, with similar effects on Tm for both DNA and RNA complexes. One abasic site present in the center of the oligomer sequence causes the respective Tm to decrease by 6 and $3{ }^{\circ} \mathrm{C}$ for DNA and RNA templates, respectively. The presence of a second $\mathrm{Y}^{\mathrm{ab}}$ group further decreases the affinity of chimeric DNA towards complementary strands of DNA or RNA by about 6-7 ${ }^{\circ} \mathrm{C}$.

Table 3. Binding affinity of oligomers 13-16 and 19a,c-21a,c towards $\mathrm{dA}_{19}, \mathrm{~A}_{19}$ and double stranded region of DNA hairpin sequence $d\left(\mathrm{~A}_{21} \mathrm{C}_{4} \mathrm{~T}_{21}\right)$. All Tm values ${ }^{a}$ were determined by the UV melting temperature measurements (details given in the Experimental section)

\begin{tabular}{|c|c|c|c|c|}
\hline \multirow[t]{2}{*}{ No } & \multirow{2}{*}{$\begin{array}{c}\text { Compound sequence } \\
\left(5^{\prime} \rightarrow 3^{\prime}\right)\end{array}$} & \multicolumn{3}{|c|}{ Target sequence $/ \mathrm{Tm}\left[{ }^{\circ} \mathrm{C}\right]^{a}$} \\
\hline & & $\mathrm{dA}_{19}$ & $\mathrm{~A}_{19}$ & $\mathrm{~d}\left(\mathrm{~A}_{21} \mathrm{C}_{4} \mathrm{~T}_{21}\right)$ \\
\hline 13 & $(\mathrm{Tp})_{9} \mathrm{Y}^{\mathrm{ab}}(\mathrm{pT})_{9}$ & 48 & 41 & 10 \\
\hline 14 & $(\mathrm{Tp})_{8} \mathrm{Y}^{\mathrm{ab}} \mathrm{pY}^{\mathrm{ab}}(\mathrm{pT})_{9}$ & 42 & 33 & no triplex formation \\
\hline 15 & $\mathrm{Y}^{\mathrm{ab}} \mathrm{p}(\mathrm{Tp})_{17} \mathrm{Y}^{\mathrm{ab}}$ & 54 & $\mathrm{nd}^{f}$ & $\mathrm{Nd}$ \\
\hline 15 & $\mathrm{Y}^{\mathrm{ab}} \mathrm{p}(\mathrm{Tp})_{17} \mathrm{Y}^{\mathrm{ab}}$ & $51^{c}$ & nd & $\mathrm{Nd}$ \\
\hline 16 & $\mathrm{Y}^{\mathrm{ab}}(\mathrm{pdA})_{17} \mathrm{pY} \mathrm{Y}^{\mathrm{ab}}$ & $52^{e}$ & nd & $\mathrm{Nd}$ \\
\hline 16 & $\mathrm{Y}^{\mathrm{ab}}(\mathrm{pdA})_{17} \mathrm{p} \mathrm{Y}^{\mathrm{ab}}$ & $51^{d}$ & nd & $\mathrm{Nd}$ \\
\hline 19a & $(\mathrm{Tp})_{9} \mathrm{Y}(\mathrm{pT})_{9}$ & 48 & 42 & 25 \\
\hline $19 \mathrm{c}$ & $(\mathrm{Tp})_{9} \mathrm{Y}(\mathrm{pT})_{9}{ }^{b}$ & 49 & 40 & 29 \\
\hline 20a & $(\mathrm{Tp})_{8} \mathrm{YpY}(\mathrm{pT})_{9}$ & 43 & 38 & 26 \\
\hline 20c & $(\mathrm{Tp})_{8} \mathrm{YpY}(\mathrm{pT})_{9}{ }^{b}$ & 43 & 36 & 30 \\
\hline $21 \mathrm{a}$ & $(\mathrm{Tp})_{8} \mathrm{YpYpY}(\mathrm{pT})_{8}$ & 39 & 32 & 27 \\
\hline 21c & $(\mathrm{Tp})_{8} \mathrm{YpYpY}(\mathrm{pT})_{8}{ }^{b}$ & 40 & 33 & 31 \\
\hline Ref. & $\mathrm{T}_{19}$ & 54 & 44 & 25 \\
\hline Ref. & $\mathrm{T}_{19}{ }^{b}$ & 54 & 45 & 28 \\
\hline
\end{tabular}

${ }^{a}$ Melting temperatures were measured at $10 \mathrm{mM}$ Tris- $\mathrm{HCl}$ buffer $\mathrm{pH} 7.4,10 \mathrm{mM} \mathrm{MgCl}, 100$ $\mathrm{mM} \mathrm{NaCl}$, with an error of $\pm 1.0{ }^{\circ} \mathrm{C}$. For determination of Tm's of complexes with oligomers 19a-21a the $10 \mathrm{mM}$ Tris- $\mathrm{HCl}$ buffer $\mathrm{pH} 7.0,10 \mathrm{mM} \mathrm{MgCl}_{2}, 100 \mathrm{mM} \mathrm{NaCl}$ was used.

${ }^{b}$ 5'-DMT-derivative.

${ }^{c}$ target sequence - oligomer 16.

${ }^{d}$ target sequence - oligomer $\mathbf{1 5}$.

${ }^{e}$ target sequence - oligomer $\mathrm{T}_{19}$.

$f$ - nd - not determined. 
Anionic groups present at the ends of oligomers, as in the case of compounds $\mathbf{1 5}$ and $\mathbf{1 6}$, have little influence on duplex stability. In this case the differences in melting temperatures of chimeric duplexes in comparison to the Tm of the non-modified duplex $\mathrm{T}_{19} / \mathrm{dA}_{19}$ are up to $3{ }^{\circ} \mathrm{C}$ (Table 3). The presence of an anionic abasic site in the third strand of the DNA triplex [as in the complex of 13 with hairpin oligomer $\mathrm{d}\left(\mathrm{A}_{21} \mathrm{C}_{4} \mathrm{~T}_{21}\right)$ ] significantly decreased triplex stability resulting in lowering of the triplex-duplex transition $\mathrm{Tm}$ by about $15^{\circ} \mathrm{C}$ per modification. No triplex formation was observed for complexes of hairpin DNA with oligomer 14 possessing two $\mathrm{Y}^{\mathrm{ab}}$ residues. Thus, as expected, the lack of either Watson-Crick or Hoogsteen interactions of $\mathrm{Y}^{\mathrm{ab}}$ units, located within the central domain of the modified oligomers, with their counterparts in corresponding duplexes and triplexes has dramatic consequences on the stability the these complexes. However, abasic BHPA units positioned at the ends of oligomers exhibit minimal influence on duplex stability (as in duplexes $15 / \mathrm{dA}_{19}, 16 / \mathrm{T}_{19}$ and $\mathbf{1 5} / \mathbf{1 6}$ ) due to smaller participation of the terminal base pairs in duplex stability. ${ }^{21}$

Hybridization affinity of chimeric phosphinate / phosphate backbone oligomers 19 - 21, containing one, two or three BHPA units with alkylnucleobase moiety, to ssDNA and RNA templates is not improved in comparison to hybridization affinity of chimeric oligomers containing abasic units $\mathrm{Y}^{\mathrm{ab}}$. The differences in Tm of non-modified complexes $\mathrm{T}_{19} / \mathrm{dA}_{19}$ and $\mathrm{T}_{19} / \mathrm{A}_{19}$ and duplexes of oligomers 19a, 19c, 20a, 20c, 21a and 21c with their DNA and RNA templates are within 2 to $6{ }^{\circ} \mathrm{C}$. The lower affinity of these novel DNA analogs towards their complementary strands probably results from their higher flexibility and the loss of entropy in comparison to natural DNA molecule. ${ }^{3,4}$ It has been proven that the more rigid structure of DNA analog (like e.g. LNA) provides better affinity to a complementary RNA strand. ${ }^{22}$ From the other side peptide nucleic acid analogs (PNA) despite their structural flexibility exhibit extremely high affinity toward their DNA and RNA complements. ${ }^{23}$

An interesting hybridization feature was found for oligomers 19a,c - 21a,c with respect to their ability to form stable triplexes with hairpin DNA $\left[\mathrm{d}\left(\mathrm{A}_{21} \mathrm{C}_{4} \mathrm{~T}_{21}\right)\right]$. Melting temperatures of these triplexes (Table 3) are identical or slightly higher than that of the reference complexes. Probably the phosphinate / phosphate backbone flexibility of the third strand has less influence on triplex stability as compared to contribution of this feature in the duplex structure.

\section{Enzymatic degradation of chimeric oligomers 13 and 14 with 3 '- and 5 '-exonucleases as analyzed by MALDI-TOF technique}

Chimeric oligomers 13 and 14, possessing one or two abasic units $\left(\mathrm{Y}^{\mathrm{ab}}\right)$ located in the central domain of the oligomer sequence (Table 2), were used to study their recognition by $3^{\prime}$ - and 5'exonucleases. Chimeric oligonucleotides were incubated with snake venom (svPDE, PDE I) and with calf spleen phosphodiesterases (PDE II), respectively and the digestion products of each reaction were identified by MALDI-TOF mass spectrometry analysis.

Figure 6a presents four subsequent MALDI-TOF mass spectra of degradation products of oligonucleotide 13 with PDE I taken after $10 \mathrm{~min}, 1,2$ and 3 hours of the cleavage reaction. A ladder of products, which differ by $\mathrm{m} / \mathrm{z} 304$, corresponds to the products of subsequent removal 
of pT nucleotides from the parent oligonucleotide $13(\mathrm{~m} / \mathrm{z} 5601)$. After 3 hours of cleavage reaction an accumulation of oligonucleotide $(\mathrm{Tp})_{9} \mathrm{Y}^{\mathrm{ab}}$ of $\mathrm{m} / \mathrm{z} 2863$ is observed. No further degradation of this product occurs even after 6 hours. These results demonstrate that cleavage of the parent oligomer undergoes up to the modification site. An analogous product $(\mathrm{Tp})_{8} \mathrm{Y}^{\mathrm{ab}} \mathrm{pY}^{\mathrm{ab}}$ of $\mathrm{m} / \mathrm{z} 2747$ is accumulated when oligomer 14 is treated with svPDE (Figure 6d). In contrary, both these oligomers, 13 and 14, when treated with PDE II nuclease, result in accumulation of the products containing one natural nucleotide upstream of the modification site. Thus, oligomer 13 is subsequently degraded to product $\mathrm{TpY}^{\mathrm{ab}}(\mathrm{pT})_{9}$ of $\mathrm{m} / \mathrm{z} 3167$ (Figure 6b), while oligomer 14 results in the formation of compound $\mathrm{TpY}^{\mathrm{ab}} \mathrm{pY}^{\mathrm{ab}}(\mathrm{pT})_{9}$ of $\mathrm{m} / \mathrm{z} 3354$ (Figure 6d).

Snake venom phosphodiesterase, which is a 3 -exonuclease, is active up to the modification site being able to cleave the phosphodiester bond between thymidine and BHPA units. In contrast, calf spleen phosphodiesterase, which is a $5^{\prime}$-exonuclease, is not able to cleave the phosphodiester bond between 5'-thymidine and BHPA units. This nuclease removes all the 5'terminal nucleotides but one upstream of the modification site. As expected, BHPA structural motives present in the DNA chain are resistant toward 3'- and 5'-exonucleases, however their recognition depends on the cleaving features of used nucleases. ${ }^{24,25} \mathrm{Y}^{\mathrm{ab}}$ units introduced at the ends of the oligomers can be a novel class of protecting "clamps" against cellular exonucleases and therefore can be used for protection of antisense, TFO, ribozyme and deoxyribozyme oligonucleotides tested in vivo or in cellular systems for their gene down-regulation activity. The added value of such protection is that BHPA abasic units located at the ends of the oligonucleotides demonstrate minimal influence on duplex stability, as it is shown in thermal stability of duplexes $15 / \mathrm{dA}_{19}, \mathbf{1 6} / \mathrm{T}_{19}$ and 15/16. We prepared several oligomers with 3'- and 5'terminal $\mathrm{Y}^{\mathrm{ab}}$ protecting groups for their screening as antisense agents (data not shown). Such phosphinic acid "clamps" were also successfully applied for the protection of deoxyribozymes, directed towards the HIV-1 viral RNA sequence in in vitro HIV-1 infected cellular experiments, ${ }^{7}$ as well as for deoxyribozymes designed to cleave bcr-abl mRNA fragments in in vitro experiments. $^{8}$

Oligonucleotides 13 and 14 and the reference oligothymidylate $T_{20}$ were also given to the cleavage reaction with 3 '-exonuclease from human plasma. ${ }^{26}$ For this assay, 5'-radiolabeled oligonucleotides were incubated with $50 \%$ human plasma. Products of degradation were analysed by PAGE under denaturing conditions (20\% polyacrylamide, $7 \mathrm{M}$ urea). The results show that the reference oligomer incubated for 8 hours at $37{ }^{\circ} \mathrm{C}$ afforded a ladder of products ranging from $\mathrm{T}_{19}$ to $\mathrm{T}_{2}$ (Figure $7 \mathrm{a}$ ). The chimeric oligomers were degraded only partially under these conditions. Degradation of oligonucleotide 13 proceeded from the 3'-terminus and was arrested by the presence of the abasic BHPA motif. As a consequence, accumulation of the product $(\mathrm{Tp})_{9} \mathrm{Y}^{\mathrm{ab}}$ was observed (Figure $7 \mathrm{~b}$ ). An analogous ladder of products, with accumulation of the product $(\mathrm{Tp})_{8} \mathrm{Y}^{\mathrm{ab}} \mathrm{pY}^{\mathrm{ab}}$ was observed for degradation of oligonucleotide 14 (results not shown). 
a
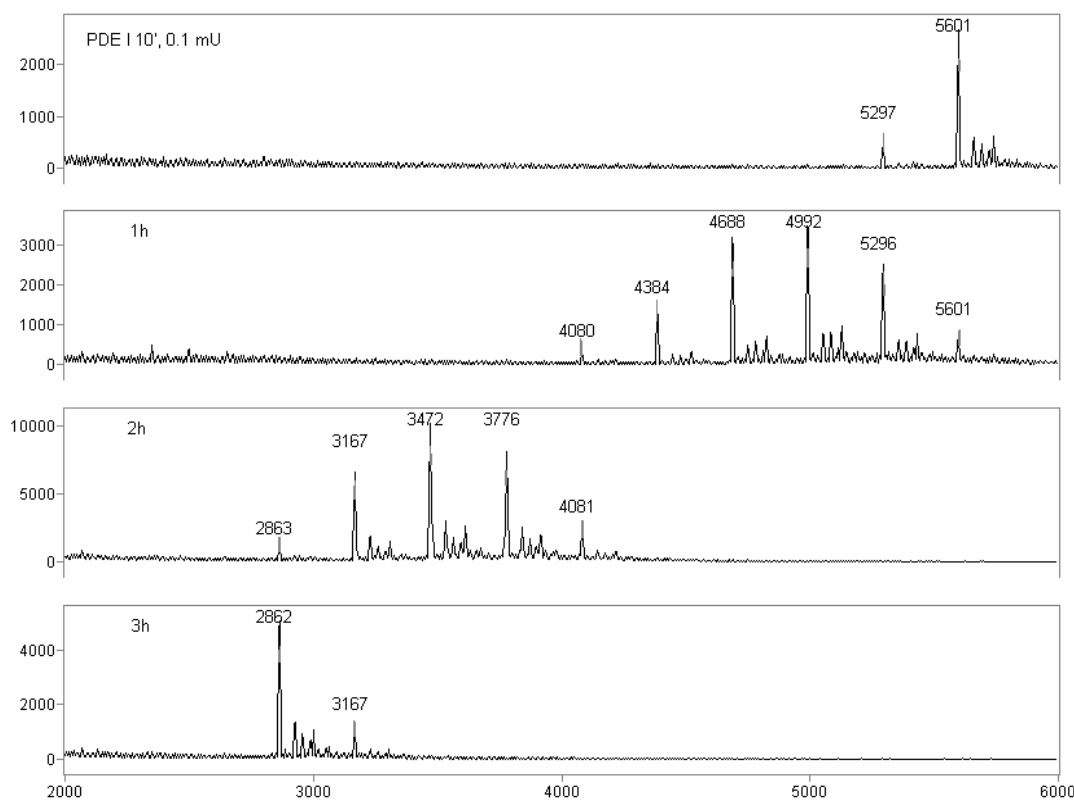

b
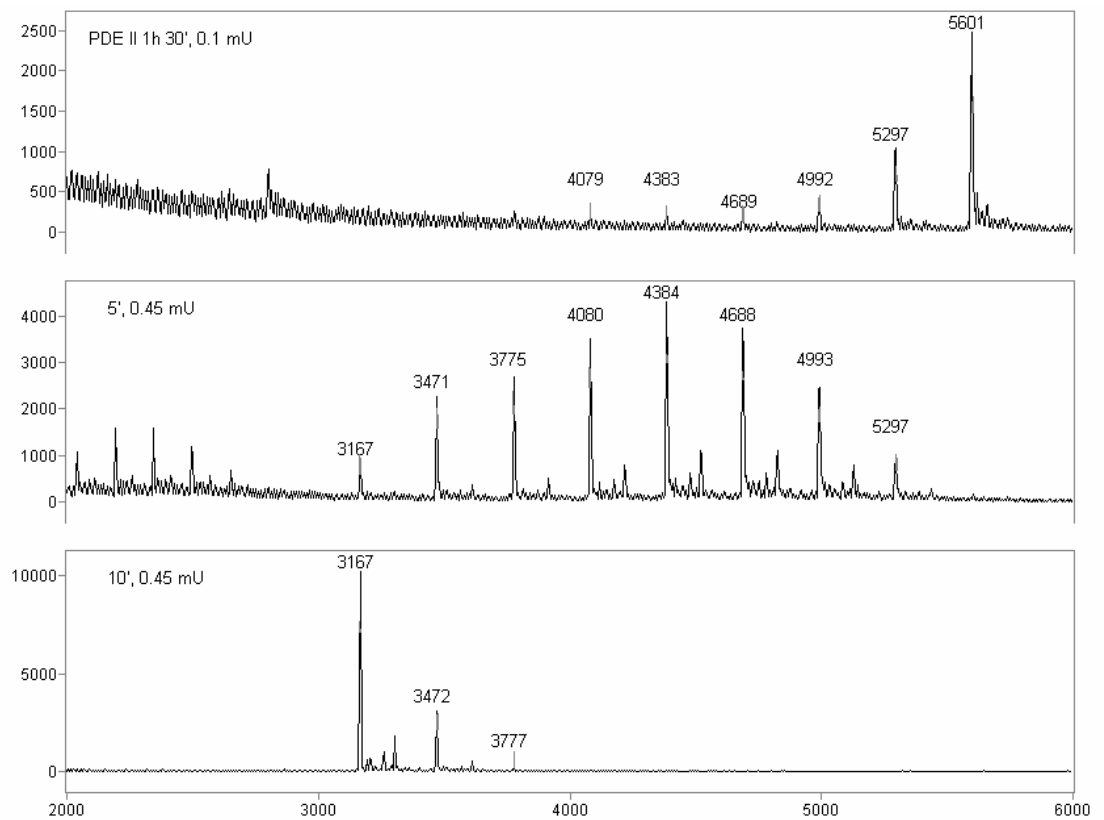

Figure 6. MALDI-TOF MS analysis of degradation products of chimeric phosphinate / phosphate oligomers 13 and $\mathbf{1 4}$ with snake venom and calf spleen phosphodiesterases (PDE I and PDE II, respectively). Oligomers were used at the concentration of $1 \mathrm{nM}$ with the amount of enzyme and the reaction time described in Experimental. MALDI-TOF mass spectra show analysis of the products of the following reactions: a - $(\mathrm{Tp})_{9} \mathrm{Y}^{\mathrm{ab}}(\mathrm{pT})_{9}$ (13) / PDE I, b (Tp $)_{9} \mathrm{Y}^{\mathrm{ab}}(\mathrm{pT})_{9}(\mathbf{1 3}) /$ PDE II. 
$\mathrm{c}$
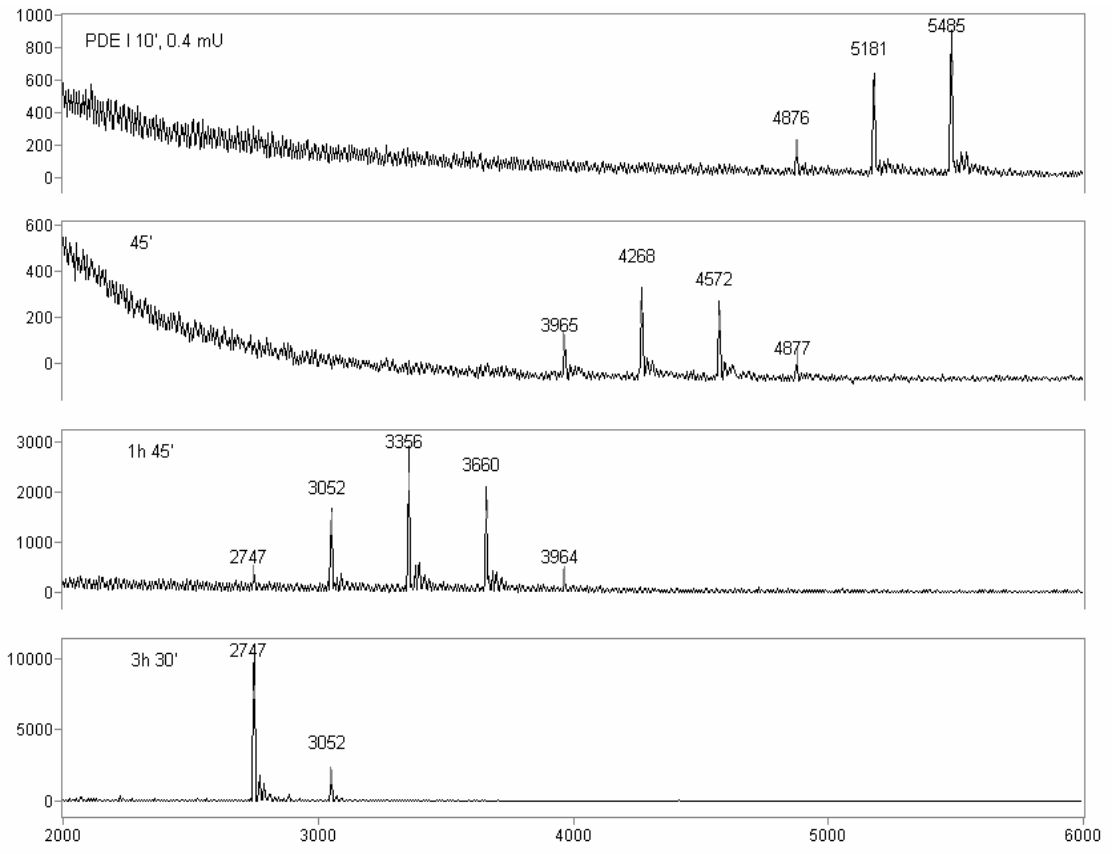

d
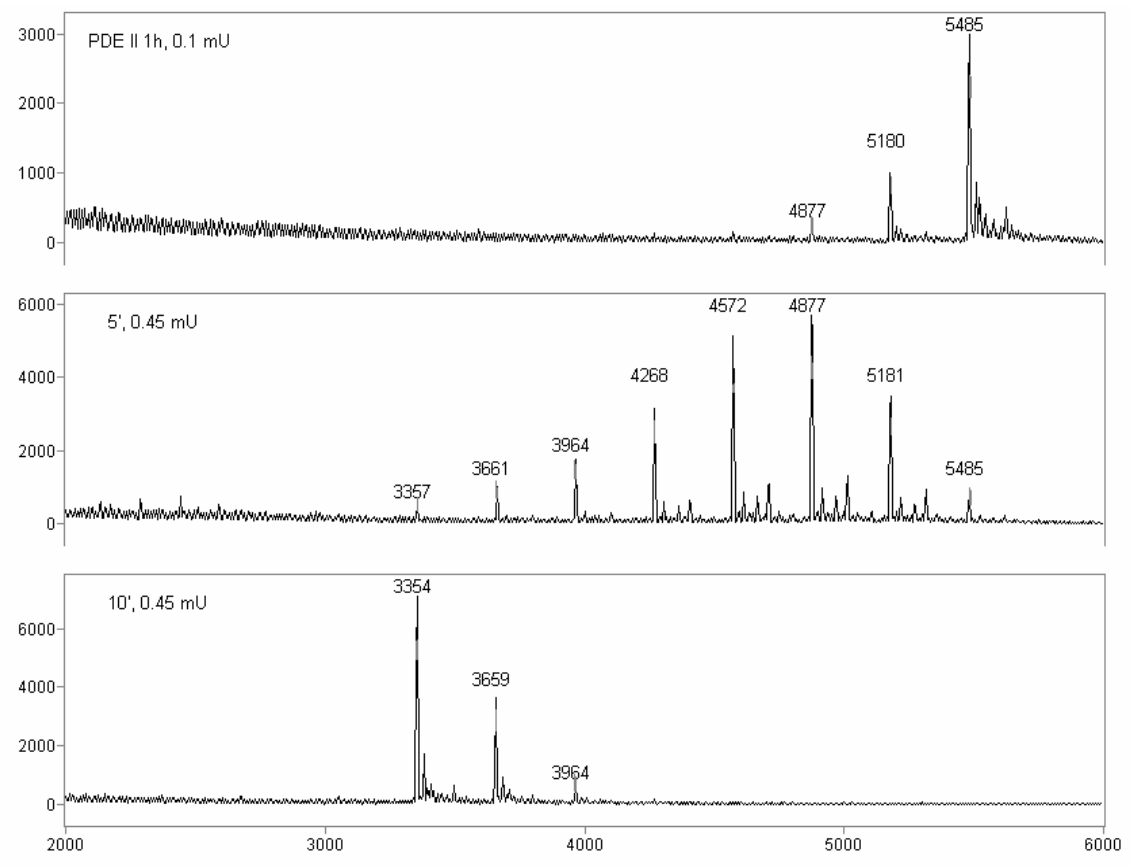

Figure 6 (continued). MALDI-TOF MS analysis of degradation products of chimeric phosphinate / phosphate oligomers 13 and 14 with snake venom and calf spleen phosphodiesterases (PDE I and PDE II, respectively). Oligomers were used at the concentration of $1 \mathrm{nM}$ with the amount of enzyme and the reaction time described in Experimental. MALDITOF mass spectra show analysis of the products of the following reactions: $c$ (Tp $)_{8} \mathrm{Y}^{\mathrm{ab}} \mathrm{pY}^{\mathrm{ab}}(\mathrm{pT})_{9}(\mathbf{1 4}) / \mathrm{PDE}$ I, d - (Tp $)_{8} \mathrm{Y}^{\mathrm{ab}} \mathrm{pY} \mathrm{Y}^{\mathrm{ab}}(\mathrm{pT})_{9}$ (14) / PDE II. 
$\mathrm{T}_{20}$
0
$\begin{array}{lllllll}0 & 30 & 1 & 2 & 4 & 6 & 8 \mathrm{~h}\end{array}$

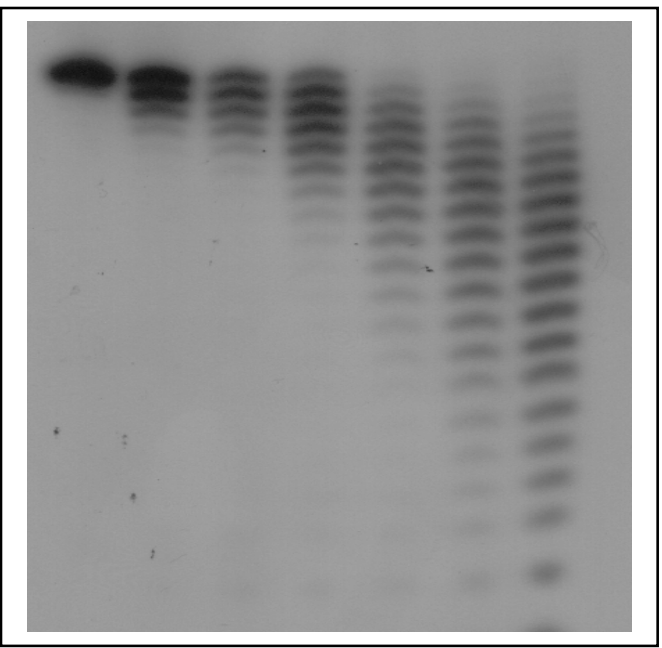

a
13

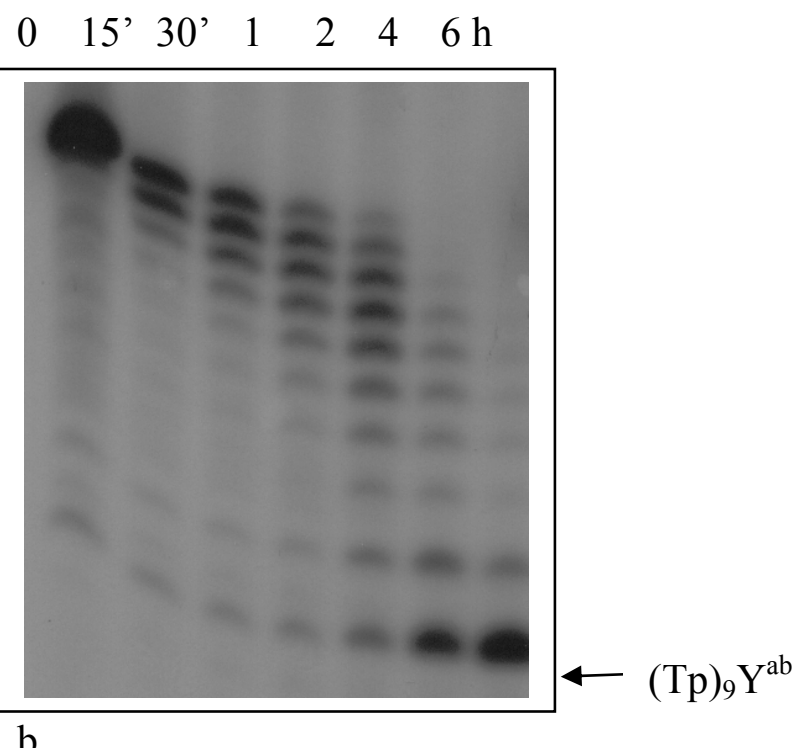

Figure 7. Degradation of $5{ }^{,}-{ }^{32} \mathrm{P}$-labeled oligomers $\mathrm{T}_{20}$ (a) and $\mathbf{1 3}\left[(\mathrm{Tp})_{9} \mathrm{Y}^{\mathrm{ab}}(\mathrm{pT})_{9}\right]$ (b) in $50 \%$ human plasma at different time points monitored by $20 \%$ polyacrylamide $/ 7 \mathrm{M}$ urea gel electrophoresis.

\section{Cytotoxicity of chimeric oligomers 17 and 18 towards HUVEC and HeLa cell lines}

For determination of cytotoxicity of chimeric phosphinate / phosphate oligomers we chose two polyanionic oligomers $\mathbf{1 7}$ and $\mathbf{1 8}$. The cytotoxicity of the test oligomers was evaluated in tumor HeLa and endothelial HUVEC cell lines with an MTT assay. ${ }^{27}$ Endothelial cells (HUVEC) were isolated and cultured as described. ${ }^{28}$ HeLa cells were cultured according to the standard method. As shown in Table 4 cytotoxicity of both polyanionic polymers toward tested cell lines was rather low. 
Table 4. Cytotoxicity of oligomers $\mathbf{1 7}$ and $\mathbf{1 8}$ toward HUVEC and HeLA cells given as percentage of living cells ${ }^{a}$

\begin{tabular}{ccccccc}
\hline Oligomer & Cell line & conc. & \multicolumn{4}{c}{ Incubation time (h) / viability (\%) } \\
\cline { 3 - 7 } & & $(\mu \mathrm{M})$ & 24 & 48 & 72 & 96 \\
\hline \multirow{3}{*}{17} & \multirow{2}{*}{ HUVEC } & 2.5 & $98.0 \pm 1.8$ & $106.3 \pm 2.9$ & $89.8 \pm 2.5$ & $111.1 \pm 4.8$ \\
& & 5.0 & $90.2 \pm 2.9$ & $92.0 \pm 2.5$ & $64.7 \pm 1.6$ & $90.7 \pm 4.7$ \\
& & 10.0 & $86.9 \pm 3.0$ & $106.3 \pm 3.7$ & $73.0 \pm 2.5$ & $97.0 \pm 1.4$ \\
\hline \multirow{3}{*}{18} & \multirow{2}{*}{ HUVEC } & 5.0 & $97.1 \pm 3.1$ & $105.1 \pm 5.2$ & $97.6 \pm 2.9$ & $92.2 \pm 2.9$ \\
& & 10.0 & $103.3 \pm 1.2$ & $102.9 \pm 3.5$ & $93.7 \pm 9.0$ & $97.8 \pm 5.7$ \\
& & 20.0 & - & $89.0 \pm 2.3$ & $93.7 \pm 0.9$ & $93.7 \pm 2.3$ \\
\hline \multirow{3}{*}{18} & \multirow{3}{*}{ HeLa } & 2.5 & $102.8 \pm 3.7$ & $95.2 \pm 6.0$ & $114.6 \pm 4.5$ & $109.0 \pm 7.0$ \\
& & 5.0 & $105.6 \pm 4.5$ & $103.2 \pm 9.7$ & $112.9 \pm 1.9$ & $97.6 \pm 15.5$ \\
& & 10.0 & $103.2 \pm 12.5$ & $100.7 \pm 3.6$ & $112.9 \pm 4.6$ & $107.3 \pm 8.9$ \\
& & 20.0 & - & $96.8 \pm 1.4$ & $97.8 \pm 10.8$ & $95.7 \pm 9.4$ \\
\hline
\end{tabular}

${ }^{a}$ Toxicity of oligomers was determined as described ${ }^{27}$ by an MTT method. Absorbance of a given sample was measured at $570 \mathrm{~nm}$, with the reference wavelength $630 \mathrm{~nm}$ (Microplate Reader 450, BioRad). The percentage of living cells $\left(\mathrm{P}_{\mathrm{LC}}\right)$ was calculated from the equation: $\mathrm{P}_{\mathrm{LC}}$ $=\left(A_{S}-A_{M}\right) /\left(A_{C}-A_{M}\right) \times 100 \%$, where As is the absorbance of a given sample of cells treated with oligomers, AM is the absorbance of a cell medium, Ac is the absorbance of a control (untreated) cells.

\section{Conclusions}

A series of novel DNA analogs, containing chimeric phosphinate / phosphate backbone could be effectively synthesized by incorporation of acylic nucleoside analogs derived from bishydroxymethylphosphinic acid (BHPA) residue into an oligonucleotide chain. Structural flexibility and loss of entropy make these chimeric oligomers unable to form stable duplexes with their complementary RNA and DNA strands. However, these oligomers possess slightly higher binding affinity towards double stranded DNA, as compared to a non-modified reference. Their low cytotoxic activity toward HUVEC and HeLa cell lines and, as expected, excellent stability toward 3'- and 5'-exonucleases does not preclude their use as therapeutic agents either as 3'- and 5'-terminal protecting groups or as triplex forming oligomers in antigene approach. 


\section{Experimental Section}

\section{General procedure for the synthesis of compounds 7}

MSNT procedure. MSNT $(0.44 \mathrm{~g}, 1.5 \mathrm{mmol})$ was added to a solution of $6(0.80 \mathrm{~g}, 1.0 \mathrm{mmol})$ and $N$-1- or $N$-3-(2-hydroxyethyl)thymine $(0.17 \mathrm{~g}, 1 \mathrm{mmol})$ in anhydrous pyridine $(8 \mathrm{~mL})$ and the mixture was stirred at RT for $24 \mathrm{~h}$. The solvent was evaporated and the crude product was isolated by column chromatography on silica gel with a gradient of $0-5 \% \mathrm{MeOH}$ in $\mathrm{CHCl}_{3}$ to give pure $7 \mathbf{a}$ or $\mathbf{7 b}$ in the form of a white foam.

Appel procedure. $\mathrm{CCl}_{4}(0.54 \mathrm{~mL}, 5.6 \mathrm{mmol})$ was added with stirring under argon at $\mathrm{RT}$ to a solution of $6(0.90 \mathrm{~g}, 1.1 \mathrm{mmol})$ and $\mathrm{PPh}_{3}(0.88 \mathrm{~g}, 3.4 \mathrm{mmol})$ in anhydrous pyridine $(8 \mathrm{~mL})$. Stirring was continued for $30 \mathrm{~min}$ and a solution of $\mathrm{N}$-1- or $\mathrm{N}$-3-(2-aminoethyl)thymine $(0.19 \mathrm{~g}$, $1.1 \mathrm{mmol})$ in anhydrous pyridine $(4 \mathrm{~mL})$ was added. The resulting solution was stirred for $24 \mathrm{~h}$ at RT and the solvent was removed under reduced pressure. The crude product was purified by silica gel column chromatography with a gradient of $0-5 \% \mathrm{MeOH}$ in $\mathrm{CHCl}_{3}$ to give pure $7 \mathbf{c}$ or $7 \mathbf{d}$ as white powder.

Yields of the reactions (\%), TLC $\mathrm{R}_{\mathrm{f}}$ values, FAB MS and ${ }^{31} \mathrm{P} \mathrm{NMR}\left(\mathrm{CHCl}_{3}\right)$ spectral data are given in Table 1.

${ }^{1} \mathrm{H}$ NMR characterization of products $7 \mathbf{a}-\mathbf{d}\left(200 \mathrm{MHz}, \mathrm{CDCl}_{3}\right)$ :

7a. 7.38-6.71 (m, 26H), $7.32(\mathrm{q}, J=1.1 \mathrm{~Hz}, 1 \mathrm{H}), 4.04(\mathrm{~m}, 4 \mathrm{H}), 3.78(\mathrm{~s}, 6 \mathrm{H}), 3.77(\mathrm{~s}, 6 \mathrm{H}), 3.69$ $(\mathrm{dd}, J=9.5 \mathrm{~Hz}, J=12.5 \mathrm{~Hz}, 2 \mathrm{H}), 3.41(\mathrm{dd}, J=9.7 \mathrm{~Hz}, J=12.5 \mathrm{~Hz}, 2 \mathrm{H}), 1.64(\mathrm{~d}, J=1.1 \mathrm{~Hz}, 3 \mathrm{H})$;

7b. 7.37-6.71 (m, 27H), $4.13(\mathrm{~m}, 4 \mathrm{H}), 3.77$ (s, 6H), 3.76 (s, 6H), 3.60 (dd, J=9.0 Hz, J=12.5 Hz, 2H), 3.42 (dd, $J=9.0 \mathrm{~Hz}, J=12.5 \mathrm{~Hz}, 2 \mathrm{H}), 1.77$ (d, $J=1.1 \mathrm{~Hz}, 3 \mathrm{H})$;

7c.7.40-6.70 (m, 26H), 7.08 (q, J=1.0 Hz, 1H), $3.77(\mathrm{~s}, 6 \mathrm{H}), 3.76(\mathrm{~s}, 6 \mathrm{H}), 3.73-3.58(\mathrm{~m}, 4 \mathrm{H})$, $3.28(\mathrm{dd}, J=9.6 \mathrm{~Hz}, J=11.5 \mathrm{~Hz}, 2 \mathrm{H}), 3.14$ (dd, $J=9.6 \mathrm{~Hz}, J=11.5 \mathrm{~Hz}, 2 \mathrm{H}), 1.76$ (d, J=1.0 Hz, 3H); 7d. $7.38-6.7(\mathrm{~m}, 26 \mathrm{H}), 7.34(\mathrm{q}, J=1.0 \mathrm{~Hz}, 1 \mathrm{H}), 4.03\left(\mathrm{t}, J_{\mathrm{PCH}}=5.7 \mathrm{~Hz}, 4 \mathrm{H}\right), 3.55$ (dd, $J=9.3 \mathrm{~Hz}$, $J=12.0 \mathrm{~Hz}, 2 \mathrm{H}), 3.77$ (s, 6H), 3.76 (s, 6H), 3.32 (dd, J=9.4 Hz, J=12.0 Hz, 2H), 1.76 (d, $J=1.0$ $\mathrm{Hz}, 3 \mathrm{H})$.

\section{General procedure for the synthesis of compounds 8a-d}

To a solution of compound $7(0.22 \mathrm{mmol})$ in $\mathrm{MeOH}(4 \mathrm{~mL})$, a methanolic solution of toluene-4sulfonic acid $(0.13 \mathrm{~mL}, 0.02 \mathrm{M})$ was added, with stirring. After $5 \mathrm{~min}$ the reaction was terminated by addition of pyridine $(0.4 \mathrm{~mL})$. The product and unreacted substrate were separated by means of preparative TLC on silica gel with $\mathrm{CHCl}_{3} / \mathrm{MeOH}(9: 1, \mathrm{v} / \mathrm{v})$. The recovered substrate again was reacted as above. After several-fold repetition of the procedure, pure product $\mathbf{8}$ was obtained as a white solid. Yields of the reactions, TLC $\mathrm{R}_{\mathrm{f}}$ values, FAB MS and ${ }^{31} \mathrm{P}$ NMR $\left(\mathrm{CHCl}_{3}\right)$ spectral data are given in Table 1. 
${ }^{1} \mathrm{H}$ NMR characterization of products $8 \mathbf{a - d}\left(200 \mathrm{MHz}, \mathrm{d}_{5}-\mathrm{Py}\right)$ :

8a. 7.77-6.80 (m, 14H), 4.98 (br. s, OH), 4.69-4.52 (m, 4H), 4.18-4.01 (m, 2H), 3.84 (t, J=3.3 $\mathrm{Hz}, 2 \mathrm{H}), 3.65$ (s, 3H), 3.64 (s, 3H), 1.85 (d, J=1.0 Hz, 3H);

8b. $7.78-6.74$ (m, 14H), 4.90 (br. s, OH), 4.46-4.20 (m, 2H), 4.17-4.03 (m, 4H), 3.79 (s, 3H), $3.78(\mathrm{~s}, 3 \mathrm{H}), 3.61-3.23(\mathrm{~m}, 2 \mathrm{H}), 1.87$ (d, $J=1.0 \mathrm{~Hz}, 3 \mathrm{H})$;

8c. $7.92-6.93$ (m, 14H), 4.98 (br. s, OH), 4.55 (d, J=3.0 Hz, 2H), 4.45-4.25 (m, 2H), 3.97-3.67 (m, 4H), $3.65(\mathrm{~s}, 6 \mathrm{H}), 1.88(\mathrm{~d}, J=1.0 \mathrm{~Hz}, 3 \mathrm{H})$;

8d. 7.81-6.86 (m, 14H), 5.19 (br. s, OH), 4.57 (m, 2H), 4.45 (t, J=6.0 Hz, 2H), 3.98-3.67 (m, 4H), 3.64 (s, 3H), 3.63 (s, 3H), 1.87 (d, J=1.0 Hz, 3H);

Synthesis of 8e was done according to routine procedure. ${ }^{29}$ Yield: $72 \%,{ }^{1} \mathrm{H}$ NMR $\left(200 \mathrm{MHz}, \mathrm{d}_{5^{-}}\right.$ Py): 7.77-6.80 (m, 13H), $4.52(\mathrm{t}, 2 \mathrm{H}), 3.99-3.64 \mathrm{ppm}(\mathrm{m}, 11 \mathrm{H}) ;{ }^{31} \mathrm{P} \mathrm{NMR}\left(\mathrm{d}_{5}-\mathrm{Py}\right) 48.50 \mathrm{ppm}$, FAB MS: $441[\mathrm{M}-\mathrm{H}], \mathrm{R}_{\mathrm{f}}=0.29\left(\mathrm{CHCl}_{3} / \mathrm{MeOH}, 9: 1, \mathrm{v} / \mathrm{v}\right)$.

\section{General procedure for phosphitylation of derivatives 8a-d}

2-Cyanoethyl $N, N, N^{\prime}, N^{\prime}$-tetraisopropylphosphordiamidite (1.2 eq. ) was added under argon to the solution of 8a-d (1.0 eq.) and 2-ethylthio- $1 H$-tetrazole (2.4 eq.) in anhydrous acetonitrile. The reaction mixture was stirred for $1 \mathrm{~h}$ at room temperature and then loaded under argon on to a silica gel column. The products 9a-d were eluted with a gradient (0-5\%) of methanol in methylene chloride, concentrated in vacuo and stored under argon at $-20{ }^{\circ} \mathrm{C}$.

Yields of these reactions (\%), TLC chromatographic mobility $\mathrm{R}_{\mathrm{f}}$ and ${ }^{31} \mathrm{P} \mathrm{NMR}\left(\mathrm{CHCl}_{3}\right)$ spectral data of 8a-d are given in Table 1 .

\section{Phosphitylation of 8e}

2-Cyanoethyl $N, N$-diisopropylphosphoramidochloridite $(296 \mu \mathrm{L}, 1.5 \mathrm{mmol})$ was added under argon to a solution of $\mathbf{8 e}(442 \mathrm{mg}, 1 \mathrm{mmol})$ and ethyl-N,N-diisopropylamine $(520 \mu \mathrm{L}, 3 \mathrm{mmol})$ in anhydrous acenitrile $(30 \mathrm{~mL})$. The reaction mixture was kept for $2 \mathrm{~h}$ at room temperature and then applied under argon on a silica gel column. The product was eluted with hexane/ethyl acetate $(1: 1, \mathrm{v} / \mathrm{v})$ and then with gradient of methanol (up to $3 \%$ ) in chloroform. Fractions containing pure phosphoramidite $9 \mathrm{e}$ were concentrated in vacuo and stored as foam under argon at $-20{ }^{\circ} \mathrm{C}$. Yield $565 \mathrm{mg}, 88 \%,{ }^{31} \mathrm{P}$ NMR $(\mathrm{MeCN}): 152.53,152.16,151.78,46.34$ and 45.97 ppm; TLC: $\mathrm{R}_{\mathrm{f}}=0.32\left(\mathrm{CHCl}_{3} / \mathrm{MeOH}, 9: 1, \mathrm{v} / \mathrm{v}\right)$

\section{Loading of 8e on a LCA CPG solid support}

The solution of 8e $(300 \mathrm{mg}, 0.7 \mathrm{mmol})$, succinic anhydride (100 mg, $1.0 \mathrm{mmol})$ and 4dimethylaminopyridine $(110 \mathrm{mg}, 0.9 \mathrm{mmol})$ in anhydrous pyridine $(10 \mathrm{~mL})$ were stirred for 24 hours at room temperature. After this time an additional portion of succinic anhydride $(21 \mathrm{mg}$, $0.05 \mathrm{mmol}$ ) was added and the reaction mixture was kept for an additional 4 hours. Then chloroform was added to the reaction mixture, the organic phase was washed twice with $2 \%$ aqueous citric acid $(2 \times 20 \mathrm{~mL})$ and once with water $(20 \mathrm{~mL})$. The organic layer was dried with 
anhydrous magnesium sulfate, filtered and then evaporated to dryness. The acyl derivative of $\mathbf{8 e}$ was loaded on a silica gel column, eluted with $\mathrm{CHCl}_{3} / \mathrm{MeOH}$ 9:1 (v/v) and dried in vacuo. Long chain aminoalkyl control pore glass (LCA CPG, CHEMGENES, Ashland Technology Center, Ashland, MA) (2g) and acyl derivative of $8 \mathbf{e}(340 \mathrm{mg}, 0.65 \mathrm{mmol})$ were dried overnight in vacuo, then dissolved in anhydrous DMF $(10 \mathrm{~mL})$ and pyridine $(1 \mathrm{~mL})$. DCC $(250 \mathrm{mg}, 1.2$ mmol) was added to this solution and the reaction mixture was shaken for 48 hours at room temperature. Then the glass was washed with anhydrous methanol/pyridine $(10 \mathrm{~mL}, 1: 1, \mathrm{v} / \mathrm{v})$ solution, with anhydrous acetonitrile $(10 \mathrm{~mL})$ and dried in vacuo. The loading efficiency was determined by DMT-cation assay. The modified solid support 9 f was loaded with the derivative 8e up to $57.0 \mu \mathrm{mol} / \mathrm{g}$.

\section{Oligonucleotide synthesis}

The 3'-O-phosphoramidite building units 9a-e were used for the synthesis of chimeric oligomers 10-21 by automated solid phase methodology. ${ }^{14}$ The $1 \mu$ mole scale synthesis of oligomers was performed on an ABI 394 synthesizer (Applied Biosystems Inc., Foster City, CA) using succinyl-or oxalyl-linked LCAA-CPG solid support. The only difference in the manufacturer's recommended protocol was a prolonged coupling time (up to $600 \mathrm{~s}$ ). The coupling efficiency was determined by DMT-ion assay.

Oligomers 10c, 10d, 11 and 18 were synthesized on succinyl-linked LAC CPG as DMT OFF constructs, cleaved from the solid support by treatment with $28 \%$ ammonium hydroxide ( $1 \mathrm{~mL})$ for $1 \mathrm{~h}$ at room temperature and purified by reverse phase semi-preparative HPLC.

Oligomers 12a, 12b, 19a-21a were synthesized on oxalyl-linked LCAA-CPG solid support as DMT OFF constructs. These oligomers were removed from the solid support by treatment with thiophenol / dioxane / triethylamine mixture $(2: 1: 2, \mathrm{v} / \mathrm{v})$ for $5 \mathrm{~min}$ at room temperature and then solid support was washes with $1 \%$ aqueous triethylamine for 7-10 min at room temperature. After solvent evaporation oligomers were purified by semi-preparative or analytical HPLC (as indicated in table 2).

Oligomers 13-17, 19c-21c were obtained as the 5'-O-DMT protected constructs. These oligomers were purified by a standard RP HPLC method (DMT ON step). The removal of 5'DMT group was achieved by treatment with $50 \%$ acetic acid for $30 \mathrm{~min}$ at room temperature, followed by the RP HPLC semi-preparative purification (DMT OFF step) to produce fully deprotected oligonucleotides with 50-80\% yield.

The structure and purity of oligomers were confirmed by MALDI-TOF mass spectrometry, $20 \%$ polyacrylamide / 7 M urea gel electrophoresis and RP HPLC analysis.

\section{Semi-preparative RP HPLC}

Semi-preparative RP HPLC was performed on a LDC Analytical system and C18 PRP-1 column (Hamilton, $305 \times 7 \mathrm{~mm}$ ) with a linear gradient of acetonitrile in $0.1 \mathrm{M}$ triethylammonium bicarbonate $\mathrm{pH} 7.5$ buffer and a flow rate $3 \mathrm{~mL} / \mathrm{min}$. Buffer $\mathrm{A}-0.1 \mathrm{M}$ triethylammonium 
bicarbonate $\mathrm{pH} 7.5, \mathrm{~B}-40 \%$ acetonitrile / $60 \% 0.1 \mathrm{M}$ triethylammonium bicarbonate $\mathrm{pH} 7.5$ buffer.

For DMT ON the gradient was as follows: 0-30 min / 0-100\% buffer B, 30-34 $\mathrm{min} / 100 \%$ B, 34-39 min / 100-0 \% B.

For DMT OFF the gradient was as follow: 0-10 $\mathrm{min} /$ 0-50 \% buffer B, 10-12 $\mathrm{min} / 50-70 \%$ B, 12-14 min / 70-100 \% B, 14-18 min / $100 \% \mathrm{~B}, 18-23 \mathrm{~min} / 100-0 \% \mathrm{~B}$.

\section{Analytical reverse phase HPLC}

Analytical RP HPLC of oligomers 10-12,19a-21a was performed on a Gilson HPLC system (Middleton, WI, USA) containing two 306 pumps, UV/VIS-151 detector and dynamic mixer $811 \mathrm{C}$ with a C18 $(4.6 \times 250 \mathrm{~mm}$, ThermoQuest) column. For elution a linear gradient of acetonitrile in $0.1 \mathrm{M}$ triethylammonium bicarbonate $\mathrm{pH} 7.5$ buffer $(0-20 \mathrm{~min} / 0-50 \% \mathrm{~B}, 20-25$ $\mathrm{min} / 20-100 \% \mathrm{~B}$, flow rate $1 \mathrm{~mL} / \mathrm{min}$ ) was used with a flow rate $1 \mathrm{~mL} / \mathrm{min}$.

Analytical RP HPLC of oligomers 19c-21c was performed on a SpectraSystem P4000 on a Hypersil ODS 5U (4.6x250 mm) Alltech column with a linear gradient as follow: 0-30 min / 0$100 \%$ buffer B, 30-34 min / $100 \%$ B, 34-39 min / 100-0 \% B at a flow rate $1 \mathrm{~mL} / \mathrm{min}$.

\section{Melting temperature measurements}

Samples for the melting temperature measurements (duplexes or triplexes) were prepared by hybridization of modified oligomers with the complementary single stranded DNA, RNA or double stranded DNA, as listed in Table 3. Melting profiles were recorded after heating up to $70{ }^{\circ} \mathrm{C}$, followed by annealing to $5^{\circ} \mathrm{C}$ with a temperature gradient of $0.5^{\circ} \mathrm{C} / \mathrm{min}$. Oligonucleotides were kept at $5{ }^{\circ} \mathrm{C}$ for $5 \mathrm{~min}$ then heated at temperature gradient of $0.2{ }^{\circ} \mathrm{C} / \mathrm{min}$ to $86{ }^{\circ} \mathrm{C}$. The melting temperatures were calculated using the first order derivative method. Measurements were performed on Cintra 40 instrument (GBC Australia).

\section{Oligonucleotide labeling}

Oligonucleotides 13, 14, 17, 19-21 were 5'-end labeled with $\left[\gamma_{-}{ }^{32} \mathrm{P}\right] \mathrm{ATP}$ and T4 polynucleotide kinase according to a previously described procedure. ${ }^{30}$

\section{Digestion of chimeric oligomers 13 and 14 with snake venom phosphodiesterase (PDE I, 3'- exonuclease)}

Oligomer 13. Water $(3.0 \mu \mathrm{l})$ and a solution of PDE I ( $1 \mu \mathrm{l}$ of Crotalus durissus phosphodiesterase, EC 3.1.15.1, Boehringer Mannheim GmbH, Germany, $0.1 \mathrm{mU} / \mu \mathrm{l}$ ) were added to a solution of modified oligonucleotide $13(1.0 \mu \mathrm{L}$ of $5 \mathrm{nM}$ stock solution) and the mixture was incubated at $37^{\circ} \mathrm{C}$. Samples $(1 \mu \mathrm{L})$ were withdrawn from the reaction mixture after $10,60,120$ and $180 \mathrm{~min}$ and analyzed by the MALDI-TOF MS.

Oligomer 14. A solution of PDE I (4 $\mu$ l of Crotalus durissus phosphodiesterase, EC 3.1.15.1, Boehringer Mannheim $\mathrm{GmbH}$, Germany, $0.1 \mathrm{mU} / \mu \mathrm{L}$ ) were added to a solution of modified oligonucleotide $14\left(1.0 \mu \mathrm{L}\right.$ of $5 \mathrm{nM}$ stock solution) and the mixture was incubated at $37^{\circ} \mathrm{C}$. One 
$\mu \mathrm{L}$ samples were withdrawn from the reaction mixture after 10, 45, 105 and $210 \mathrm{~min}$ and analyzed by the MALDI-TOF MS.

\section{Digestion of chimeric oligomers 13 and 14 with calf spleen phosphodiesterase (PDE II, 5'- exonuclease)}

Oligomer 13. A solution of oligonucleotide 13 (1 $\mu \mathrm{L}$ of a $5 \mu \mathrm{M}$ stock solution) was mixed with water $(3 \mu \mathrm{L})$ and a solution of PDE II (1 $\mu \mathrm{L}$ of calf spleen phosphodiesterase, EC 3.1.16.1, Sigma, St. Louis, MO, U.S.A., $0.1 \mu \mathrm{g} / \mu \mathrm{L}$ ). The mixture was incubated at $37{ }^{\circ} \mathrm{C}$. A sample of 1 $\mu \mathrm{L}$ was withdrawn from the reaction mixture after $90 \mathrm{~min}$. The next samples prepared from oligonucleotide 13 (1.5 $\mu \mathrm{L}$ of a $5 \mu \mathrm{M}$ stock solution), a solution of PDE II (4.5 $\mu \mathrm{L}$ of calf spleen phosphorodiesterase, $0.1 \mu \mathrm{g} / \mu \mathrm{L})$ and water $(1.5 \mu \mathrm{L})$ were withdrawn from the reaction mixture after 5 and 10 min and analyzed by MALDI-TOF MS.

Oligomer 14. A solution of oligonucleotide $14(1 \mu \mathrm{L}$ of a $5 \mu \mathrm{M}$ stock solution) was mixed with water $(3 \mu \mathrm{L})$ and a solution of PDE II ( $1 \mu \mathrm{L}$ of calf spleen phosphorodiesterase, EC 3.1.16.1, Sigma, St. Louis, MO, U.S.A., $0.1 \mu \mathrm{g} / \mu \mathrm{L}$ ). The mixture was incubated at $37^{\circ} \mathrm{C}$. Sample of $1 \mu \mathrm{L}$ was withdrawn from the reaction mixture after $60 \mathrm{~min}$. The next samples prepared from oligonucleotide 14 (1.5 $\mu \mathrm{L}$ of a $5 \mu \mathrm{M}$ stock solution), a solution of PDE II (4.5 $\mu \mathrm{L}$ of calf spleen phosphorodiesterase, $0.1 \mu \mathrm{g} / \mu \mathrm{L})$ and water $(1.5 \mu \mathrm{L})$ were withdrawn from the reaction mixture after 5 and $10 \mathrm{~min}$ and analyzed by MALDI-TOF MS.

\section{MALDI-TOF measurements}

Samples $(1 \mu \mathrm{L})$ withdrawn from the digestion reactions were put on a sample plate, mixed with the matrix solution [ $1 \mu \mathrm{L}$ of an $8 / 1, \mathrm{v} / \mathrm{v}$ mixture of 2,4,6-trihydroxyacetophenone $(10 \mu \mathrm{g} / \mathrm{mL}$ in ethanol) and diammonium citrate $(50 \mu \mathrm{g} / \mathrm{mL}$ in water $)]$ and left for crystallization. MALDI-TOF spectra were recorded on a Voyager-Elite instrument (PerSeptive Biosystems, CT) in the reflector mode, at a resolution of $2000 . \mathrm{M} / \mathrm{z}$ negative ion peaks are shown at the spectra.

\section{Cell cultures}

The Human epithelioid cervical carcinoma cell line (HeLa) was maintained in RPMI 1640 medium (Gibco BRL, Paisley, UK) supplemented with 10\% thermally inactivated foetal bovine serum (FBS, Gibco BRL, Paisley, UK), $100 \mu \mathrm{g} / \mathrm{mL}$ streptomycin and $100 \mathrm{U} / \mathrm{mL}$ penicillin. Human umbilical vein endothelial cells (HUVEC) were isolated from freshly collected umbilical cords as previously described (Jaffe et al., 1973), and cultured in plastic dishes coated with gelatin, in RPMI 1640 medium supplemented with 20\% FBS, $90 \mathrm{U} / \mathrm{ml}$ heparin, 150 $\mu \mathrm{g} / \mathrm{mL}$ ECGF (Endothelial Cell Growth Factor, Roche Diagnostics, Mannheim, Germany) and antibiotics (as above). All cell lines were grown in monolayer, at $37^{\circ} \mathrm{C}$ in an atmosphere of $5 \%$ $\mathrm{CO}_{2}$. 


\section{Cytotoxicity studies}

The cytotoxicity of oligomers $\mathbf{1 7}$ and $\mathbf{1 8}$ was studied for HeLa and HUVEC cell lines using an MTT [3-(4,5-dimethylthiazol-2-yl)-2,5-diphenyltetrazolium bromide; Sigma, St. Louis, MO] assay (activity of the mitochondrial respiratory chain). ${ }^{27}$ Cells were trypsinized and diluted with appropriate culture medium to a density of 5000 cells $/ 200 \mu \mathrm{L}$ for tested cells. Cell suspensions were added to the 96 -well plates $(200 \mu \mathrm{L}$ per well). After 24 hours of cell cultivation oligonucleotides were added to a final concentration of $2.5 \mu \mathrm{M}$. The cells were incubated for 72 hours in the presence of tested oligonucleotides. As controls, cultured cells were grown in the absence of oligonucleotides. After 72 hours of incubation, $25 \mu 1$ of MTT solution $(5 \mathrm{mg} / \mathrm{mL})$ in PBS was added to each well and incubated for additional 2 hours at $37^{\circ} \mathrm{C}$. Finally, $95 \mu \mathrm{L}$ of lysis buffer (20\% SDS, $50 \%$ aqueous dimethylformamide, $\mathrm{pH} 4.5$ ) was added into each well and incubated at $37^{\circ} \mathrm{C}$ for additional 24 hours. Absorbance of a given sample was measured at 570 $\mathrm{nm}$, with the reference wavelength $630 \mathrm{~nm}$ (Microplate Reader 450, BioRad). The percentage of living cells $\left(\mathrm{P}_{\mathrm{LC}}\right)$ was calculated from the equation:

$$
P_{L C}=\left(A_{S}-A_{M}\right) /\left(A_{C}-A_{M}\right) \times 100 \%
$$

where $A_{S}$ is the absorbance of a given sample of cells treated with oligomers, $A_{M}$ is the absorbance of a cell medium, $\mathrm{A}_{\mathrm{C}}$ is the absorbance of a control (untreated) cells.

HeLa cells were cultured according to the standard method.

Data points represent means of at least three measurements.

\section{Acknowledgments}

Financial support from The State Committee for Scientific Research in Poland is gratefully acknowledged (project PBZ-KBN-059/T09/09). Authors would like to thank Dr. Steven Patterson for critical reading of the manuscript.

\section{References}

1. Zamecnik, P.; Stephenson, M.L. Proc. Natl. Acad. Sci. USA 1978, 75, 260.

2. Giovannangeli, C.; Hélène, C. Antisense Nucleic Acids Drug Dev. 1997, 7, 413.

3. Habus, I.; Agrawal, S. Nucleosides Nucleotides 1995, 14, 1853.

4. Schneider, K. Ch.; Benner, S.A. J. Am. Chem. Soc. 1990, 112, 453.

5. Xiang, G.; McLauglin, L.W. Tetrahedron 1998, 54, 375.

6. Nawrot, B.; Michalak, O.; Nowak, M.; Okruszek, A.; Dera M.; Stec, W.J. Tetrahedron Lett. 2002, 43.

7. Nawrot, B., Tanabe, T., Taira, K., Stec, W.J. unpublished results 
8. Taira, K.; Warashina, M.; Nawrot, B.; Obika, S.; Kuwabara, T.; Imanishi, T.; Stec, W.J. Therapeutic Application Of Chemically Modified DNA Enzymes: In Synthetic Nucleic Acids As Inhibitors Of Gene Expression: Mechanisms, Applications And Therapeutic Implications; Nova Science Publishers: Hauppauge, NY, 2003, in preparation

9. Appel, R. Angew. Chem., Int. Ed. 1975, 14, 801.

10. Romanenko, V. D.; Kornuta, P. P.; Markowski, L. N. Zh. Obshch. Khim.; RU 1978, 48, 1182.

11. Gi, H.-J.; Xiang, Y.; Schinazi, R. F.; Zhao, K. J. Org. Chem. 1997, 62, 88.

12. Nawrot, B.; Michalak, O.; Olejniczak, S.; Wieczorek, M.W.; Lis, T; Stec, W. J. Tetrahedron 2001, 57, 3979.

13. Adams, S. P.; Kavka, K. S.; Wykes, E. J.; Holder, S. B.; Galluppi, G. R. J. Am. Chem. Soc. 1983, 105, 661.

14. Caruthers, M. H. Science 1985, 230, 281.

15. Alul, R. H.; Singman, Ch. N.; Zhang, G.; Letsinger, L. Nucleic Acids Res. 1991, 19, 1527.

16. Moody, H. M.; Quaedflieg, P. J.; Koole, L. H.; van Genderen, M. H.; Buck, H. M.; Smit, L.; Jurriaans, S.; Geelen, J. L.; Goudsmit, J. Science 1990, 250, 125.

17. Koziolkiewicz, M.; Wilk, A. Methods Mol. Biol. 1993, 20, 207.

18. Iyer, R.P,; Uznanski, B.; Boal, J.; Storm, C.; Egan, W.; Matsukura, M.; Broder, S.; Zon, G.; Wilk, A.; Koziolkiewicz, M.; et al. Nucleic Acids Res. 1990, 18, 2855.

19. Zon, G.; Stec, W.J. In Oligonucleotides and Analogues. A Practical Approach; Eckstein, F., Ed.; IRL Press at Oxford University Press: Oxford, 1991, p 87.

20. Matteucci, M. D.; Caruthers, M. H. Tetrahedron Lett. 1980, 21, 3243.

21. Cantor, C.R.; Schimmel, P.R. Biophysical Chemistry 1980, Vol. I-III, Freeman \& Co.: San Francisco.

22. Christensen, U.; Jacobsen, N.; Rajwanshi, V.K.; Wengel, J.; Koch, T. Biochem J. 2001, 354, 481.

23. Demidov, V.V.; Yavnilovich, M.V.; Belotserkovskii, B.P.; Frank-Kamenetskii, M.D.; Nielsen, P.E. Proc. Natl. Acad. Sci. USA. 1995, 92, 2637.

24. Weinfeld, M.; Liuzzi, M.; Paterson, M.C. Nucleic Acids Res. 1989, 17, 3735.

25. Niewiarowski, W.; Uznanski, B. Eur. J. Biochem. 1985, 153, 145.

26. Nawrot, B.; Boczkowska, M.; Wojcik, M.; Sochacki, M.; Kazmierski, S.; Stec, W.J. Nucleic Acids Res. 1998, 26, 2650.

27. Hansen, M.B.; Nielsen, S.E.; Berg, K. J. Immunol. Methods 1989, 119, 203.

28. Jaffe, E.A.; Nachman, R.L.; Mimick, C.R. J. Clin. Invest. 1973, 52, 2745.

29. Current Protocols in Nucleic Acids Chemistry, ed. A.L. Boyle, John Wiley \& Sons: New York, 2000, Chapter 3.

30. Koziołkiewicz, M.; Wojcik, M.; Kobylanska, A.; Karwowski, B.; Rebowska, B.; Guga, P.; Stec, W. J. Antisense Nucleic Acids Drug Dev. 1997, 7, 43. 